\title{
Combining old and new evidence to increase the known biodiversity value of the Sahamalaza Peninsula, Northwest Madagascar
}

Samuel G. Penny ${ }^{1,2,3}$, Angelica Crottini ${ }^{4}$, Franco Andreone ${ }^{5}$, Adriana Bellati ${ }^{6}$, Lovasoa M.S. Rakotozafy ${ }^{7}$, Marc W. Holderied $^{2}$, Christoph Schwitzer ${ }^{1}$, Gonçalo M. Rosa ${ }^{8,9,10,11^{*}}$

${ }^{1}$ Bristol Zoological Society, clo Bristol Zoo Gardens, Clifton, Bristol, BS8 3HA, UK

${ }^{2}$ School of Biological Sciences, Life Sciences Building, University of Bristol, Tyndall Avenue, Bristol, BS8 1TQ, UK

${ }^{3}$ School of Pharmacy and Biomolecular Science, Huxley Building, University of Brighton, Lewes Road, Brighton, BN2 4GJ, UK

${ }^{4}$ CIBIO, Research Centre in Biodiversity and Genetic Resources, InBIO, Universidade do Porto, Campus Agrário de Vairão, Rua Padre Armando Quintas, $N^{\circ}$ 7, 4485-661 Vairão, Portugal

${ }^{5}$ Museo Regionale di Scienze Naturali, Via G. Giolitti, 36, I-10123, Torino, Italy

${ }^{6}$ Dipartimento di Scienze della Terra e dell'Ambiente, Università di Pavia, Via Ferrata 1, 27100 Pavia, Italy

${ }^{7}$ Mention Zoologie et Biodiversité Animale, Faculté des Sciences, Université d'Antananarivo, BP 906 Antananarivo 101, Madagascar

${ }^{8}$ Department of Biology, University of Nevada, Reno, N Virgina St, Reno, NV 89557, USA

${ }^{9}$ Institute of Zoology, Zoological Society of London, Regent's Park, NWI 4RY London, UK

${ }^{10}$ Durrell Institute of Conservation and Ecology, School of Anthropology and Conservation, University of Kent, Canterbury, Kent, CT2 7NR, UK

${ }^{11}$ Centre for Ecology, Evolution and Environmental Changes (CE3C), Faculdade de Ciências da Universidade de Lisboa, Bloco C2, Campo Grande, 1749-016 Lisboa, Portugal

* corresponding author: goncalo.m.rosa@gmail.com

Keywords: Amphibia, Squamata, integrative taxonomy, conservation, species inventory, Sambirano, molecular identification

\begin{abstract}
Prior herpetological surveys in 1996 and 2000 identified 14 species of amphibians and 32 species of reptiles from the Sahamalaza Peninsula. This work increases the total number of amphibian and reptile species known from this area to 20 and 43 respectively. To maximise our chances of species detection, survey effort covered the entire wet season and part of the dry season, and utilised a combination of opportunistic searching, transect searching, pitfall trapping, and acoustic recording. We identified species through an integrative taxonomic approach, combining morphological, bioacoustic and molecular taxonomy. Together, this enabled the detection of cryptic and seasonally inactive species that were missed in the shorter prior surveys that relied on morphological identification alone. The taxonomic identification of amphibians utilised a fragment of the mitochondrial 16S rRNA gene; taxonomic identification of reptiles utilised a fragment of the mitochondrial COI gene, and when necessary, also mitochondrial fragments of the 16S rRNA ND1, ND2, ND4 genes. All sequences were deposited in Genbank and COI sequences were also deposited in the BOLD database to foster taxonomic identification of malagasy reptiles. We report two new taxa: a species of Boophis, since described as B. ankarafensis, and a candidate new species of microhylid (genus: Stumpffia). We document range expansions of Boophis tsilomaro, Cophyla berara, Blaesodactylus ambonihazo beyond their type localities. Along with significant range expansions across a range of taxa, including Blommersia sp. Ca05, Boophys brachy-
\end{abstract}

chir, Brookesia minima, Ebenavia inunguis, Geckolepis humbloti, Madascincus stumpffi, Pelomedus subrufa and Phelsuma kochi. Forest in the peninsula is under extreme pressure from human exploitation. Unless unsustainable agricultural and pastoral practices encroaching on these habitats halt immediately, both forest and the species that occur there, several of which appear to be local endemics, may be irreversibly lost.

\section{Contents}

Introduction ....................................................................... 274

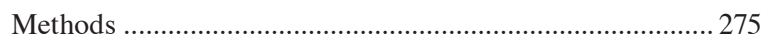

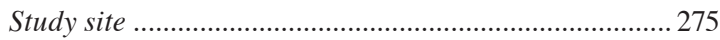

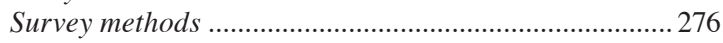

Molecular taxonomic identification ................................2276

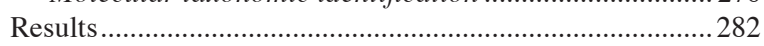

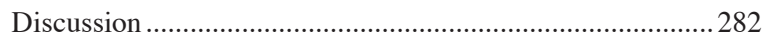

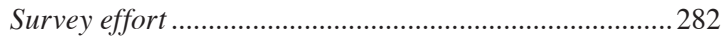

Species composition of the Sahamalaza Peninsula ....... 283

Range extensions ............................................................... 283

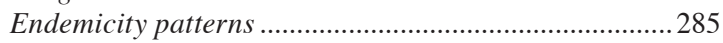

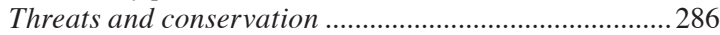

Acknowledgements ............................................................ 286

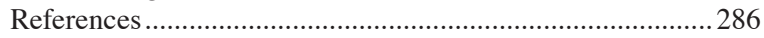

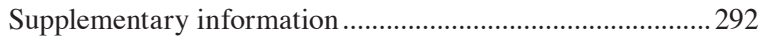




\section{Introduction}

Madagascar ranks amongst the richest countries in the world for the diversity of its herpetofauna, harbouring about 400 described species of non-avian reptiles (from here onward, we will use the traditional term 'reptiles' for species included in the Sauropsida excluding birds) and about 320 described species of amphibians (Glaw and Vences, 2007; Perl et al., 2014; AmphibiaWeb, 2017). The uniqueness of present-day Madagascan biota can be partially explained by the biogeographic isolation of the island. Indeed, much of Madagascar's extant fauna is the result of succesful colonizations around the K-T boundary at ca. 60-70 mya (Crottini et al., 2012; Samonds et al., 2012). The Madagascan herpetofauna shows remarkably high levels of endemism, with $92 \%$ of non-marine reptile species and all but one of the native amphibian species found nowhere else (Glaw and Vences, 2007).

Over the last few years, large-scale taxonomic inventories, using a combination of molecular tools, bioacoustics and morphological methods have led to a rapid increase in species descriptions and in the identification of a large number of candidate species that await description (Vieites et al., 2009; Nagy et al., 2012; Rosa et al., 2012; Perl et al., 2014). Many of the newly identified taxa are easily diagnosable, while many other species that were thought to be relatively widespread across Madagascar represent complexes of several species. This resulted in several taxonomic revisions (mostly at the genus level) and in a remarkable number of new or resurrected amphibian and reptile species [e.g. Aglyptodactylus (Köhler et al., 2015), Boophis (Glaw et al., 2010), Blommersia (Andreone et al., 2010), Gephyromantis (Vences et al., 2017), Guibemantis (Lehtinen et al., 2011), Mantidactylus (Bora et al., 2011), Scaphiophryne (Raselimanana et al., 2014), Anodontyla (Vences et al., 2010a), Cophyla (Rakotoarison et al., 2015), Platypelis (Rosa et al., 2014), Rhombophryne (Scherz et al., 2016); Stumpffia (Rakotoarison et al., 2017), Brookesia (Glaw et al., 2012), Furcifer (Florio et al., 2012), Calumma (Gehring et al., 2011), Chalarodon (Miralles et al., 2015), Zonosaurus (Raselimanana et al., 2006), Madascincus (Miralles et al., 2011), Paracontias (Miralles et al., 2016), Paragehyra (Crottini et al., 2015), Uroplatus (Ratsoavina et al., 2011), Phelsuma (Crottini et al., 2011), Liopholidophis (Glaw et al., 2014)].

Amphibians are experiencing an unprecedented worldwide decline, $41 \%$ of the described species are threatened with extinction (Monastersky, 2014) and species loss is occurring at more than 200 times the average background extinction rate (Roelants et al., 2007). Many reptile species are also in decline. In a representative sample of 1500 species nearly one fifth were found to be threatened (Böhm et al., 2013). The leading causative factors are the destruction, alteration, and fragmentation of habitats (Stuart et al., 2004; Andreone et al., 2005; Sodhi et al., 2008; Irwin et al., 2010; Jenkins et al., 2014). Having lost one third of its primary forest since the 1970s, Madagascar is no exception, and it continues to lose around $8600 \mathrm{~km}^{2}$ $(0.5 \%)$ of primary forest per year (FAO 2015). This loss will have a tremendous impact on all unique biodiversity of Madagascar, including amphibian and reptile species due to their specific habitat requirements coupled with a high dependency on the stability and quality of their habitats (Andreone et al., 2005; Sinervo et al., 2010; Riemann et al., 2015), and most probably also on human communities.

Climatic change is likely to intensify the effects of Madagascar's habitat loss (Raxworthy et al., 2008; Huey et al., 2009; Walls et al., 2013), as will the recent discovery of potentially emergent infectious pathogens (Bletz et al., 2015a, 2015b; Kolby et al., 2015), and the introduction of invasive species (Andreone et al., 2014; Crottini et al., 2014; Kolby et al., 2014; Vences et al., 2017).

A large proportion of Madagascar's amphibian and reptile diversity is limited to the island's northern and eastern rainforest slopes, which are known to host a high number of endemic species (e.g. Rosa et al., 2012; Heinermann et al., 2015; Brown et al., 2016). In recent years, high levels of species diversity have also been described from the west of the island (e.g. D'Cruze et al., 2006; Mercurio et al., 2008; Bora et al., 2010). Many reptile and amphibian species are known exclusively from western dry forests, such as several species of Gerrhosauridae (Raselimanana, 2003), Opluridae (Raselimanana et al., 2000) and tree frogs (Penny et al., 2014), most of which have narrow ranges. Dry forests, in particular those in the sub-arid regions of Madagascar, are poorly understood in terms of flora and fauna (Sussman and Rakotozafy, 1994). Malagasy deciduous dry forests declined in primary forest cover from $12.5 \%$ in 1950 to $2.8 \%$ in 1990 (Smith, 1997) and, due to their susceptibility to fire and conversion to agricultural land, are among one the most threatened habitats in the country (Janzen, 1988; Pons et al., 2003; Elmqvist et al., 2007). Forest destruction was further exacerbated by a political coup in 2009 , which led to a weakening in government enforcement (Schuurman 

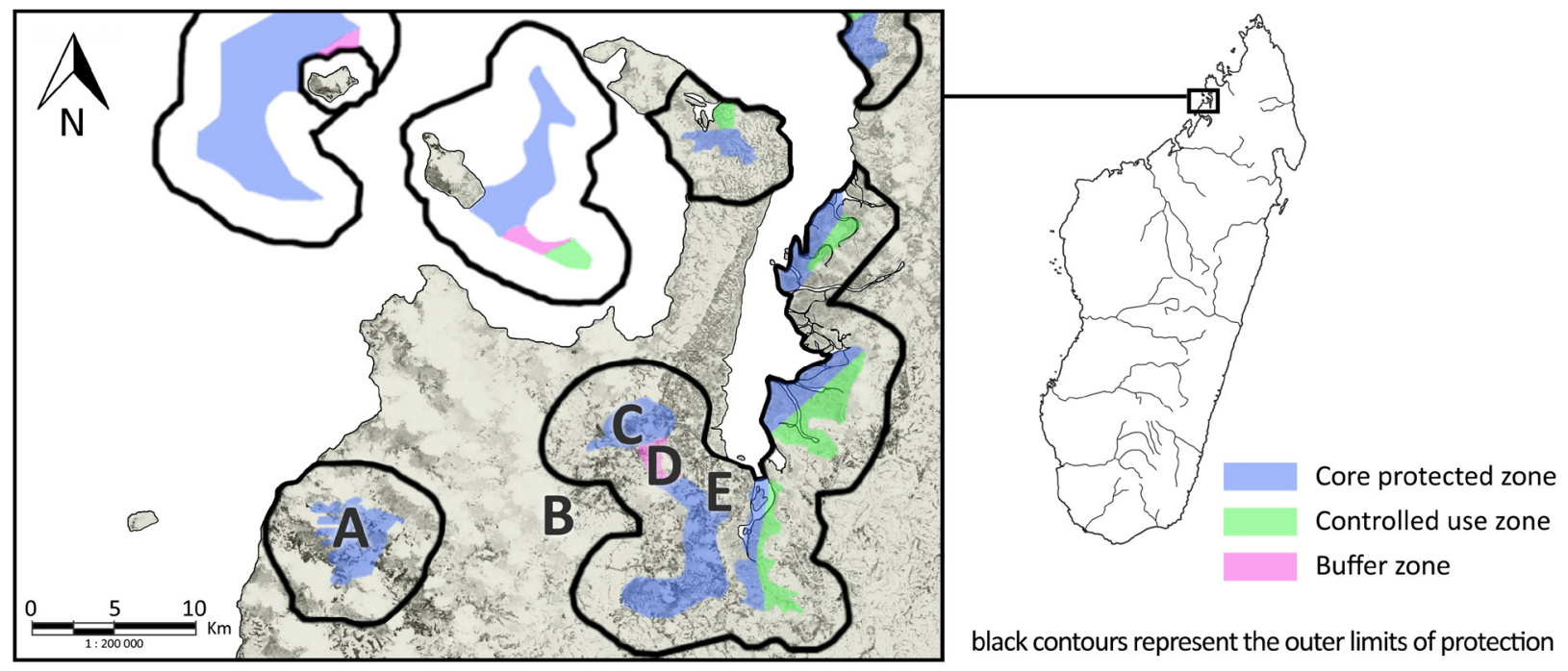

Figure 1. The Sahamalaza Peninsula in northwestern Madagascar, indicating the study sites of (A) Ankarafa Forest, (B) Antafiabe village, (C) Berara (Anabohazo Forest), (D) Anketsakely (Anabohazo Forest) and (E) Betsimipoaka village.

and Andreone, 2010; Andreone et al., 2012; Schwitzer et al., 2014). Despite acquiring formal protection in 2007, the Sahamalaza Peninsula, in western Madagascar, still experiences high levels of anthropogenic pressure on its terrestrial, freshwater and marine ecosystems (Schwitzer et al., 2007; Seiler et al., 2012; Penny et al., 2014). No large intact areas of primary forest remain, with forest consigned to a matrix of small isolated fragments, all of which show some degree of anthropogenic disturbance and/or edge effects (Schwitzer et al., 2007). The human communities living in the periphery of the protected area depend on subsistence agriculture (through 'slash-and-burn') and fishing for their livelihoods, which traditionally occurred in the core zones of the park.

A total of 14 species of amphibians and 32 species of reptiles were previously documented from the Sahamalaza Peninsula (Andreone et al., 2001; Raselimanana, 2008). The conservation importance of this community is high, due to the presence of several microendemic and threatened species. Species with spatially narrow niches are often more sensitive to the microhabitat changes associated with disturbance, thus it is particularly important to collect further ecological and distributional data on them (Glos et al., 2008; Irwin et al., 2010). To implement an effective conservation plan for Sahamalaza's herpetofauna it is crucial to increase our knowledge on the distribution and ecology of the species that occur here (Penny et al., 2016), particularly for the local endemics that were discovered before much of the recent habitat destruction had occurred. Using an integrative taxonomic approach to species identification, we here provide an update on the presence and distribution of amphibian and reptile species found on the Sahamalaza Peninsula.

\section{Methods}

Study site

Surveys took place in the Sahamalaza Peninsula, in the province of Mahajanga, Northwest Madagascar (Figure 1). The peninsula covers approximately 26,000 hectares and is defined by the Sahamalaza Bay to the east, the Mozambique Channel to the west and the Loza River to the south (Volampeno, 2009). Parts of the peninsula were designated a UNESCO Biosphere Reserve in 2001, followed by the creation of the Sahamalaza-Îles Radama National Park in July 2007 (Schwitzer et al., 2007).

The area has a sub-humid climate with two distinct seasons: a hotter, wetter season from December to April and a cooler, drier season from May to November. Monthly mean maximum temperature ranges from $28.5 \pm 3.61{ }^{\circ} \mathrm{C}$ in July to $39.1 \pm 2.11{ }^{\circ} \mathrm{C}$ in February; while monthly mean minimum temperature ranges from $13.2 \pm 0.81{ }^{\circ} \mathrm{C}$ in October to $21.8 \pm 0.81$ ${ }^{\circ} \mathrm{C}$ in January (Volampeno et al., 2011). The mean 
annual precipitation rate is around $1600 \mathrm{~mm}$ (Schwitzer et al., 2007). This climate supports a unique type of hybrid forest, consisting of plant species from both the wetter Sambirano domain and drier Western domain (Birkenshaw, 2004; Schwitzer et al., 2006). The forest consists of a matrix of small fragments isolated by savannah, all subjected to high levels of human disturbance (Schwitzer et al., 2007).

Prior herpetological survey efforts were focused on Analavory Forest (14²3.30’ S, 4756.15' E; Raselimanana, 2008), since destroyed by fire in 2004 (Volampeno, 2009), and the Berara Forest fragment in Anabohazo (14²18.6' S, 47 $54.9^{\prime} \mathrm{E}$; Andreone et al., 2001). The present survey revisited Anabohazo, including the fragment of Anketsakely in addition to Berara, and surveyed the Ankarafa Forest $\left(14^{\circ} 22.8^{\prime} \mathrm{S}, 47^{\circ} 45.5^{\prime} \mathrm{E}\right)$ for the first time. The surroundings of Antafiabe (14 $21.3^{\prime} \mathrm{S}$,

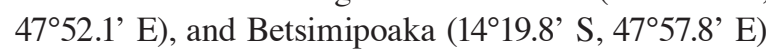
villages were also surveyed. Surveys were conducted between October 2011 and January 2012, and between January and February 2013. This ensured coverage of the entire wet season, when individuals are expected to be more active, and the end of the dry season.

\section{Survey methods}

Survey methods included opportunistic searching, transect searching, pitfall trapping and acoustic recording. Transect searches were repeated during the day and night to account for any diel differences in activity, taking place in the morning and evening. Searching took place approximately two metres either side of the transect and up to two metres in height, and for amphibians were directed towards vocalising males. Searches in Ankarafa occurred in both the dry and wet season (during the 2011 period) and followed the same routes where possible. Sites were sampled in a randomised order and all searches were conducted by the same two individuals to avoid systematic observer bias. Location was logged using a handheld GPS receiver (Garmin eTrex Vista HCx; Garmin International Inc., Olathe, USA). Representative individuals were photographed to document their coloration, using a digital camera; tissue samples were collected, as were call recordings of amphibians. An integrative taxonomic approach was taken to assess species identification of both amphibians and reptiles; utilising the keys provided by Glaw and Vences (2007, and subsequent publications), personal photographic and acoustic catalogues, the application of molecular taxonomic identification as well as the comparative material hosted in the herpetological collection of the Museo Regionale di Scienze Naturali, Torino, Italy.

Pitfall traps with drift fences were made by sinking plastic buckets (270 $\mathrm{mm}$ deep, 220-250 $\mathrm{mm}$ internal diameter) into the ground at $6 \mathrm{~m}$ intervals along a $30 \mathrm{~m}$ drift fence, $0.4 \mathrm{~m}$ high, and buried $50 \mathrm{~mm}$ deep. Plant detritus was placed in the bottom of each bucket to act as a refuge for animals and holes punched in the bottom to allow water to drain. The pitfalls were checked each morning and evening for captured animals, and nontarget animals were released. An initial four pitfall lines constructed in Ankarafa Forest in October 2011 were checked for a period of 13-15 days; these proved to be ineffective and inefficient, so a large scale expansion of pitfall trapping was discounted. A further three pitfall lines were constructed in Ankarafa Forest along a ridge, a slope and a valley bottom, for two periods of 14-15 days in October/November 2011 and December/January 2011-2012, covering the dry and wet seasons.

\section{Molecular taxonomic identification}

Tissue samples were collected with a maximum of five individuals per species-level taxon per population. If individuals appeared to belong to new and undescribed species, a limited number of voucher specimens were collected, as advised by the Code of Zoological Nomenclature (ICZN 1999). These were anaesthetised (by immersion in MS222), and fixed in 10\% buffered formalin or $90 \%$ ethanol, and later transferred in 65-75\% ethanol. Voucher specimens were deposited in the Museo Regionale di Scienze Naturali, Torino, Italy, the Parc Botanique et Zoologique de Tsimbazaza (PBZT), Antananarivo, Madagascar, and Mention Zoologie et Biodiversité Animale, Faculté des Sciences, Université d'Antananarivo, Madagascar (UADBA). Most of the tissue samples were collected in the 2013 expedition and only a small number of tissue samples were collected in the 2011-2012 surveys.

Total genomic DNA was extracted from the tissue samples using proteinase $\mathrm{K}$ digestion $(10 \mathrm{mg} / \mathrm{ml}$ concentration) followed by a standard salt extraction protocol (Bruford et al., 1992). A fragment of ca. 550 bp of the 3' terminus of the mitochondrial 16S rRNA gene (16S), proven to be suitable for amphibian identification (Vences et al., 2005a), was amplified for 78 amphibian tissue samples, while a fragment of around $650 \mathrm{bp}$ of the standard barcoding region of the cytochrome c oxidase subunit I gene (COI) (Nagy et al., 2012) was amplified for 42 reptile tissue samples and one amphibian (Table S1). In reptiles the molecular taxonomic 
Table 1. Primer information (gene fragment, primer name, sequence, literature source) and PCR conditions used for the present study.

\begin{tabular}{|c|c|c|c|c|}
\hline Gene & Primer name & Sequence (5'-3') & Source & PCR conditions \\
\hline \multirow[t]{2}{*}{ 16S rRNA } & AC_16s_ar & CGCCTGTTTATCAAAAACAT & Palumbi et al. (1991) & \multirow{2}{*}{$\begin{array}{l}94(90),[94(45), 55 \\
(45), 72(90) \times 33], 72 \\
(600)\end{array}$} \\
\hline & AC_16s_br & CCGGTYTGAACTCAGATCAYGT & $\begin{array}{l}\text { Modified from } \\
\text { Palumbi et al. (1991) }\end{array}$ & \\
\hline \multirow[t]{2}{*}{ COI } & RepCOI-F & TNTTMTCAACNAACCACAAAGA & Nagy et al. (2012) & \multirow{2}{*}{$\begin{array}{l}94(180),[94(40), 49 \\
(30), 72(60) \times 40], 72 \\
(420)\end{array}$} \\
\hline & RepCOI-R & ACTTCTGGRTGKCCAAARAATCA & Nagy et al. (2012) & \\
\hline \multirow[t]{2}{*}{ COI amphibians } & $\operatorname{dgLCO} 1490$ & GGTCAACAAATCATAAAGAYATYGG & Meyer et al. (2005) & \multirow{2}{*}{$\begin{array}{l}94(90),[94(30), 49 \\
(45), 72(90) \times 35], 72 \\
(600)\end{array}$} \\
\hline & dgHCO2198 & TAAACTTCAGGGTGACCAAARAAYCA & Meyer et al. (2005) & \\
\hline \multirow{2}{*}{$\begin{array}{l}\text { ND1 + associated } \\
\text { tRNAs }\end{array}$} & ND1 intf2 & AAYCGVGCVCCWTTYGACCTWACAGA & Schmitz et al. (2005) & \multirow{2}{*}{$\begin{array}{l}95(120),[95(30), 50 \\
(30), 72(60) \times 40], 72 \\
(600)\end{array}$} \\
\hline & ND1 tmet & TCGGGGTATGGGCCCRARAGCTT & $\begin{array}{l}\text { Leaché and Reeder } \\
\text { (2002) }\end{array}$ & \\
\hline \multirow[t]{2}{*}{ ND2 } & Ala-R2 & AAAATRTCTGRGTTGCATTCAG & Macey et al. (1997) & \multirow{2}{*}{$\begin{array}{l}94(90),[94(30), 45 \\
(45), 72(90) \times 35], 72 \\
(600)\end{array}$} \\
\hline & ND2_f17 & TGACAAAAAATTGCNCC & Macey et al. (2000) & \\
\hline \multirow[t]{2}{*}{ ND4 } & ND4 & CACCTATGACTACCAAAAGCTCATGTAGA AGC & $\begin{array}{l}\text { Modified from } \\
\text { Arévalo et al. (1994)* }\end{array}$ & \multirow[t]{2}{*}{$\begin{array}{l}94(90),[94(45), 47 \\
(45), 72(90) \times 33], 72 \\
(600)\end{array}$} \\
\hline & leutRNA & AGCCATTACTTTTACTTGGATTTGCACC & $\begin{array}{l}\text { Modified from } \\
\text { Arévalo et al. (1994)* }\end{array}$ & \\
\hline
\end{tabular}

* modified primer sequences developed by Ed Louis, Omaha’s Henry Doorly Zoo.

identification using the mitochondrial COI fragment was not possible for some taxa. In these instances, the mitochondrial gene fragments $16 \mathrm{~S}$ or NADH dehydrogenase subunits 1, 2 and 4 (ND1, ND2, ND4) were amplified and sequenced for a selected number of samples to allow a finer taxonomic identification (see Table S1). For primers and cycling protocols see Table 1. All fragments were sequenced using an ABI 3730XL automated sequencer by Macrogen Inc.

Chromatographs were checked and sequences were edited, where necessary, using the BioEdit sequence alignment editor (version 7.0.5.3; Hall, 1999). To assess the species attribution and the genetic distinctness of each taxa, sequences of each morphological taxa were compared among each other and each sequence was than compared using the BLAST algorithm in GenBank.

Some specimens could not be assigned to any described or identified candidate species as in Vieites et al. (2009), Perl et al. (2014) or Nagy et al. (2012). For these taxa we applied the terms and abbreviations, confirmed candidate species (CCS), unconfirmed candi- date species (UCS) and deep conspecific lineage (DCL) as defined by Vieites et al. (2009). Working names of the already identified candidate species follow Perl et al. (2014) for amphibians and Nagy et al. (2012) for reptiles. Additionally, when available, we used the names proposed by Glaw and Vences (2007) which usually prefix the species epithet with "sp. aff." of the morphologically closest described species or a descriptor that is either geographic or refers to a characteristic trait of the candidate species. Candidate species of amphibians were identified based on a threshold of $5 \%$ minimum divergence for the 16S fragment (Vences et al., 2005a; Fouquet et al., 2007; Vieites et al., 2009), whereas candidate species of reptiles were identified following the different thresholds proposed for the different groups as in Nagy et al. (2012). Obtained sequences were submitted to GenBank (Accession Numbers are available in Table S1) and reptile COI sequences were associated to the BOLD database.

Automated acoustic recording took place at 37 locations. Recordings were made with a single Song Meter SM2 digital recorder (Wildlife Acoustics Inc, 
Table 2. Distribution of amphibian and reptile species of the Sahamalaza Peninsula. The survey at Analavory Forest was conducted by Raselimanana (2008), while previous surveys at Anabohazo Forest and Betsimipoaka village were conducted by Andreone et al. (2001). The most recent survey conducted in 2011-13 revisited Anabohazo Forest and Betsimipoaka village, and also surveyed Ankarafa Forest and Antafiabe village and its surroundings. * species ID limited to photographic record. $\dagger$ species ID limited to observation only. CCS: confirmed candidate species, UCS: unconfirmed candidate species, DCL: deep conspecific lineage (according to Vieites et al., 2009).

\begin{tabular}{|c|c|c|c|c|c|c|c|c|}
\hline & \multirow{2}{*}{ Authority } & \multirow{2}{*}{$\begin{array}{c}\text { Analavory } \\
1996\end{array}$} & \multicolumn{2}{|c|}{ Betsimipoaka } & \multicolumn{2}{|c|}{ Anabohazo } & \multirow{2}{*}{$\begin{array}{c}\text { Ankarafa } \\
2011-13\end{array}$} & \multirow{2}{*}{$\begin{array}{c}\text { Antafiabe } \\
2011\end{array}$} \\
\hline & & & 2000 & 2013 & 2000 & 2011-13 & & \\
\hline \multicolumn{9}{|l|}{ Amphibians } \\
\hline Aglyptodactylus securifer & Glaw et al., 1998 & & & + & + & + & + & \\
\hline Blommersia sp. Ca05 (UCS) & & & & + & & + & + & \\
\hline Boophis ankarafensis & Penny et al., 2014 & & & & & & + & \\
\hline Boophis brachychir & (Boettger, 1882) & & & & & + & + & + \\
\hline Boophis jaegeri & Glaw \& Vences, 1992 & & & & + & + & + & \\
\hline Boophis tephraeomystax & (Duméril, 1853) & + & & + & & + & + & + \\
\hline Boophis tsilomaro & Vences et al., 2010 & & & & + & + & & \\
\hline Cophyla berara & Vences et al., 2005 & & & & + & + & + & + \\
\hline Gephyromantis pseudoasper & (Guibé, 1974) & & & & + & + & & \\
\hline Heterixalus luteostriatus & (Andersson, 1910) & & + & + & & + & + & \\
\hline Heterixalus tricolor* ${ }^{*}$ & (Boettger, 1881) & & & & & & + & \\
\hline Hoplobatrachus tigerinus & (Daudin, 1803) & & & & & + & + & + \\
\hline Laliostoma labrosum* & (Cope, 1868) & + & & & & & & \\
\hline Mantella ebenaui & (Boettger, 1880) & & + & & + & + & + & \\
\hline Mantidactylus ulcerosus & (Boettger, 1880) & & & + & + & + & + & + \\
\hline Platypelis sp. (UCS)* & & & & & + & & & \\
\hline Ptychadena mascareniensis & (Duméril \& Bibron, 1841) & + & & + & & + & + & + \\
\hline Rhombophryne sp. (UCS)* & & & & & + & & & \\
\hline Stumpffia gimmeli* ${ }^{*}$ & Glaw \& Vences, 1992 & & & & + & + & + & \\
\hline $\begin{array}{l}\text { Stumpffia sp. aff. pygmaea Ca } \\
\text { "Sahamalaza" (UCS) }\end{array}$ & & & & & & + & + & \\
\hline \multicolumn{9}{|l|}{ Reptiles } \\
\hline Acrantophis madagascariensis* & (Duméril \& Bibron, 1844) & & & & & + & + & \\
\hline Alluaudina bellyi & Mocquard, 1894 & & & & + & & & \\
\hline Amphiglossus reticulatus & (Kaudern, 1922) & + & & & + & + & + & \\
\hline Blaesodactylus ambonihazo & Bauer et al., 2011 & + & & & & & + & \\
\hline Brookesia minima & Boettger, 1893 & & & & & & + & \\
\hline Brookesia stumpffi & Boettger, 1894 & & & & + & + & + & \\
\hline Crocodylus niloticus $^{\dagger}$ & Laurenti, 1768 & & & & & & & + \\
\hline Dromicodryas bernieri ${ }^{*}$ & (Duméril et al., 1854) & & & & & + & + & \\
\hline Dromicodryas quadrilineatus* & (Duméril et al., 1854) & + & & & + & + & + & + \\
\hline
\end{tabular}




\begin{tabular}{|c|c|c|c|c|c|c|c|c|}
\hline & \multirow{2}{*}{ Authority } & \multirow{2}{*}{$\begin{array}{c}\text { Analavory } \\
1996\end{array}$} & \multicolumn{2}{|c|}{ Betsimipoaka } & \multicolumn{2}{|c|}{ Anabohazo } & \multirow{2}{*}{$\begin{array}{c}\text { Ankarafa } \\
2011-13\end{array}$} & \multirow{2}{*}{$\begin{array}{c}\text { Antafiabe } \\
2011\end{array}$} \\
\hline & & & 2000 & 2013 & 2000 & 2011-13 & & \\
\hline Ebenavia inunguis (clade $\mathrm{Cb}$ ) & Boettger, 1878 & & & & & & + & \\
\hline Flexiseps tanysoma $*$ & (Andreone \& Greer, 2002) & & & & + & & + & \\
\hline Furcifer oustaleti & (Mocquard, 1894) & + & + & & & + & + & + \\
\hline Furcifer pardalis & (Cuvier, 1829) & + & & & + & + & + & + \\
\hline Geckolepis humbloti & Vaillant, 1887 & + & & & + & + & + & \\
\hline $\begin{array}{l}\text { Geckolepis sp. aff. maculata } \\
\text { (OTU A; CCS) }\end{array}$ & & & & & & + & & \\
\hline Hemidactylus mercatorius & Gray, 1842 & & + & + & & & + & + \\
\hline Ithycyphus miniatus & (Schlegel, 1837) & & & & + & & & \\
\hline Ithycyphus perineti* & Domergue, 1986 & & & & & + & + & \\
\hline Leioheterodon madagascariensis* & Duméril \& Bibron, 1854 & + & + & & & + & + & + \\
\hline Liophidium torquatum* & (Boulenger, 1888) & & & & + & + & + & \\
\hline Lycodryas granuliceps & (Boettger, 1877) & & & & + & + & & \\
\hline Lygodactylus tolampyae & (Grandidier, 1872) & + & & & + & + & + & \\
\hline Madagascarophis colubrinus & (Schlegel, 1837) & + & & & + & + & + & \\
\hline Madascincus stumpffi & (Boettger, 1882) & & & & + & + & + & \\
\hline Mimophis mahfalensis* & (Grandidier, 1867) & + & & & & + & + & + \\
\hline Oplurus cuvieri & (Gray, 1831) & + & + & + & & + & + & + \\
\hline Paracontias hildebrandti & (Peters, 1880) & + & & & & & & \\
\hline Paroedura oviceps* & (Boettger, 1881) & & & & + & + & & \\
\hline Paroedura stumpffi & (Boettger, 1879) & & & & + & + & & \\
\hline Pelomedusa subrufa & (Lacépède, 1788) & & & + & & & + & \\
\hline Phelsuma abbotti* & Stejneger, 1893 & + & & & + & & & + \\
\hline Phelsuma kochi & Mertens, 1954 & + & + & & + & + & + & + \\
\hline Phelsuma laticauda* & (Boettger, 1880) & & & & & & + & \\
\hline Phelsuma sp. aff. quadriocellata (UCS)* & & & & & & & + & \\
\hline Phelsuma vanheygeni* & Lerner, 2004 & & & & & & + & \\
\hline Pseudoacontias menamainty* & Andreone \& Greer, 2002 & & & & + & & & \\
\hline Sanzinia madagascariensis & (Duméril \& Bibron, 1844) & + & & & + & & & \\
\hline Thamnosophis lateralis* & (Duméril et al., 1854) & + & & & + & + & & + \\
\hline Trachylepis elegans* & (Peters, 1854) & + & + & & & + & + & \\
\hline $\begin{array}{l}\text { Trachylepis gravenhorstii } \\
\text { (lineage } 1, \mathrm{DCL} \text { ) }\end{array}$ & (Duméril \& Bibron, 1839) & & & & + & + & + & + \\
\hline Uroplatus ebenaui & Boettger, 1879 & & & & + & + & + & \\
\hline Uroplatus henkeli & Böhme \& Ibisch, 1990 & + & & & + & + & + & \\
\hline Zonosaurus laticadatus & (Grandidier, 1869) & + & & & + & + & + & + \\
\hline
\end{tabular}




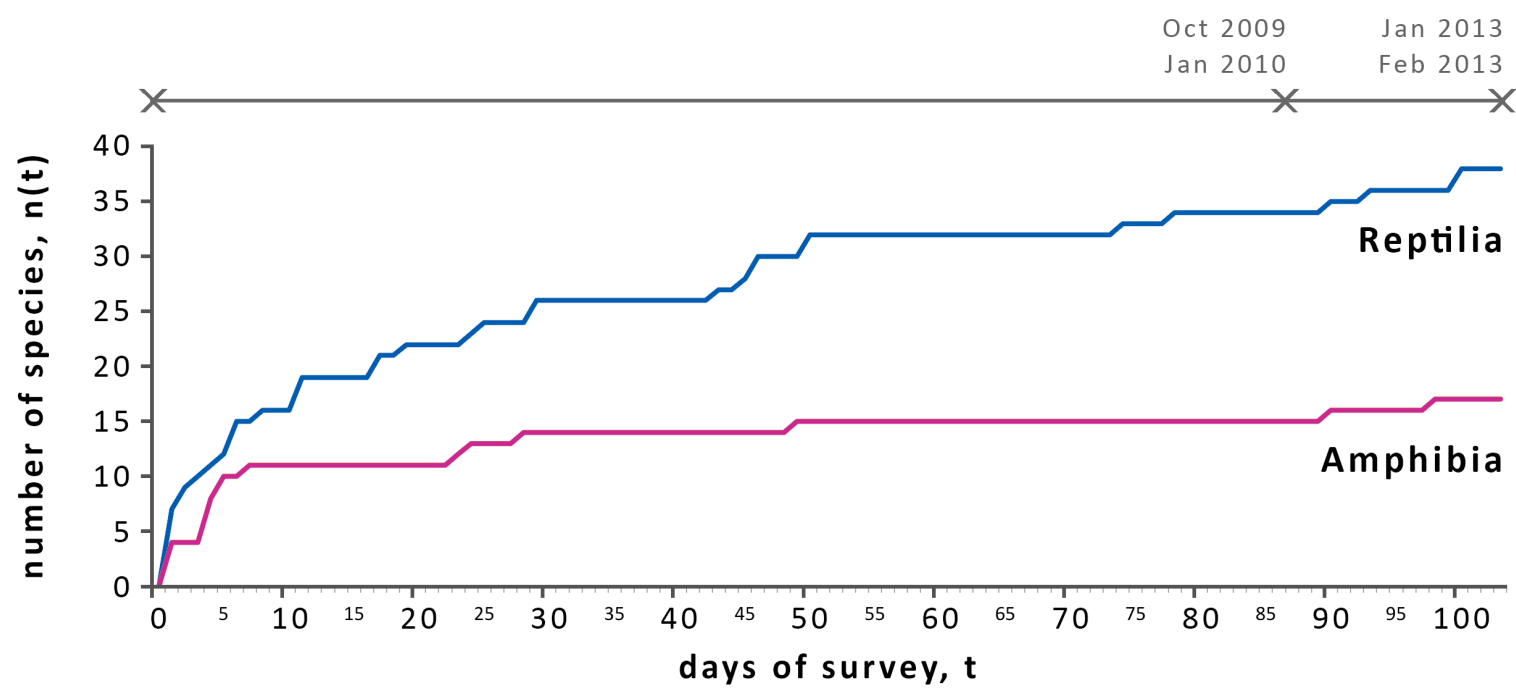

Figure 2. Species accumulation curves (based on all sampling techniques) for amphibian and reptiles species in Sahamalaza Peninsula. Curves show the accumulation during the full duration of the project, covering the wet season.
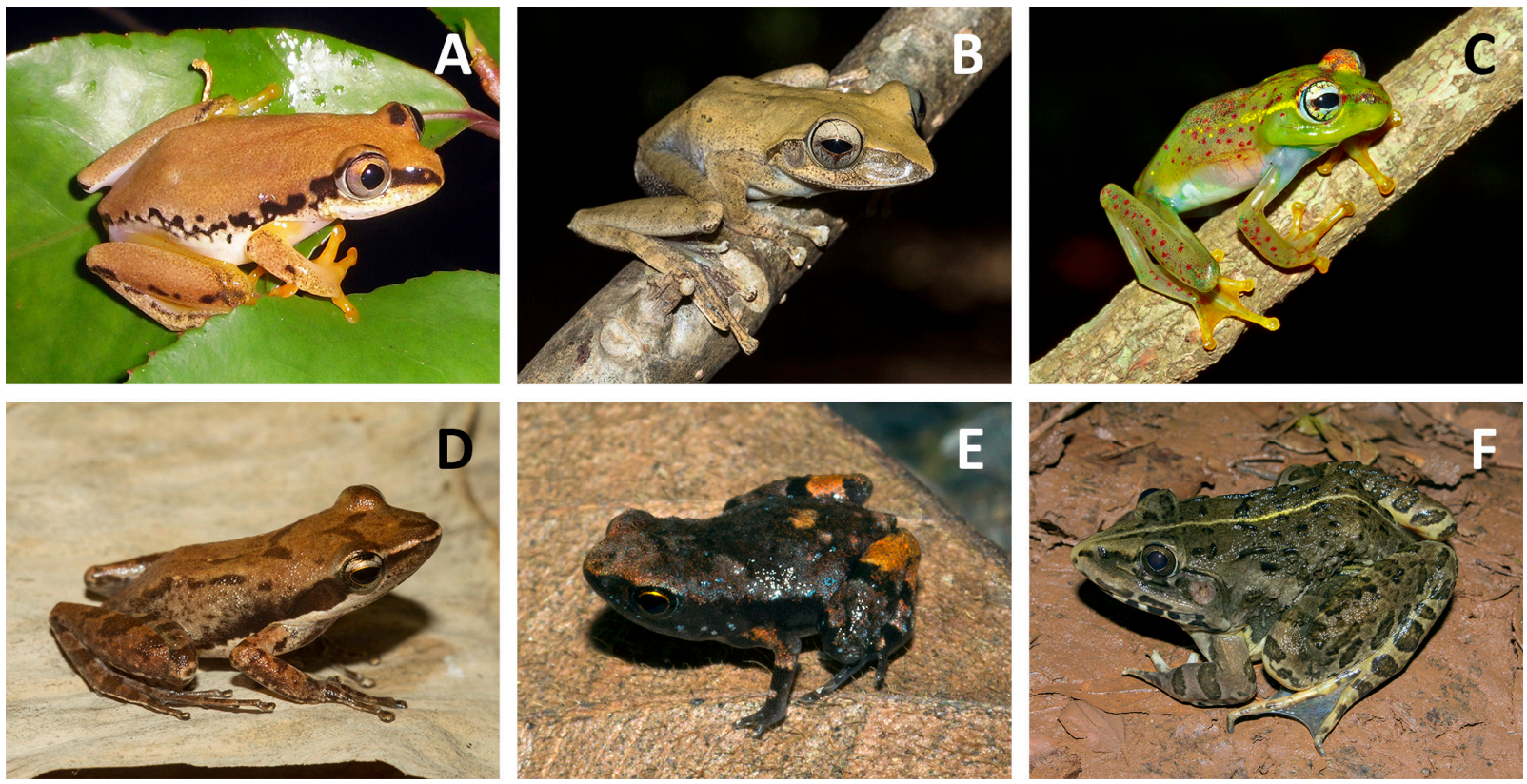

Figure 3. Amphibian species documented for the first time from the Sahamalaza Peninsula during the survey period 2011-2013: A. Heterixalus tricolor from Ankarafa Forest; B. Boophis brachychir from Ankarafa Forest; C. Boophis ankarafensis recently described from Ankarafa Forest; D. Blommersia sp. Ca05 (UCS), a candidate species reported from Ankarafa Forest; E. Stumpffia sp. aff. pygmaea Ca "Sahamalaza" (UCS), a candidate species reported from Ankarafa Forest; F. Hoplobatrachus tigerinus from Anketsakely. Photo A by S. Penny, B-F by G. M. Rosa. 

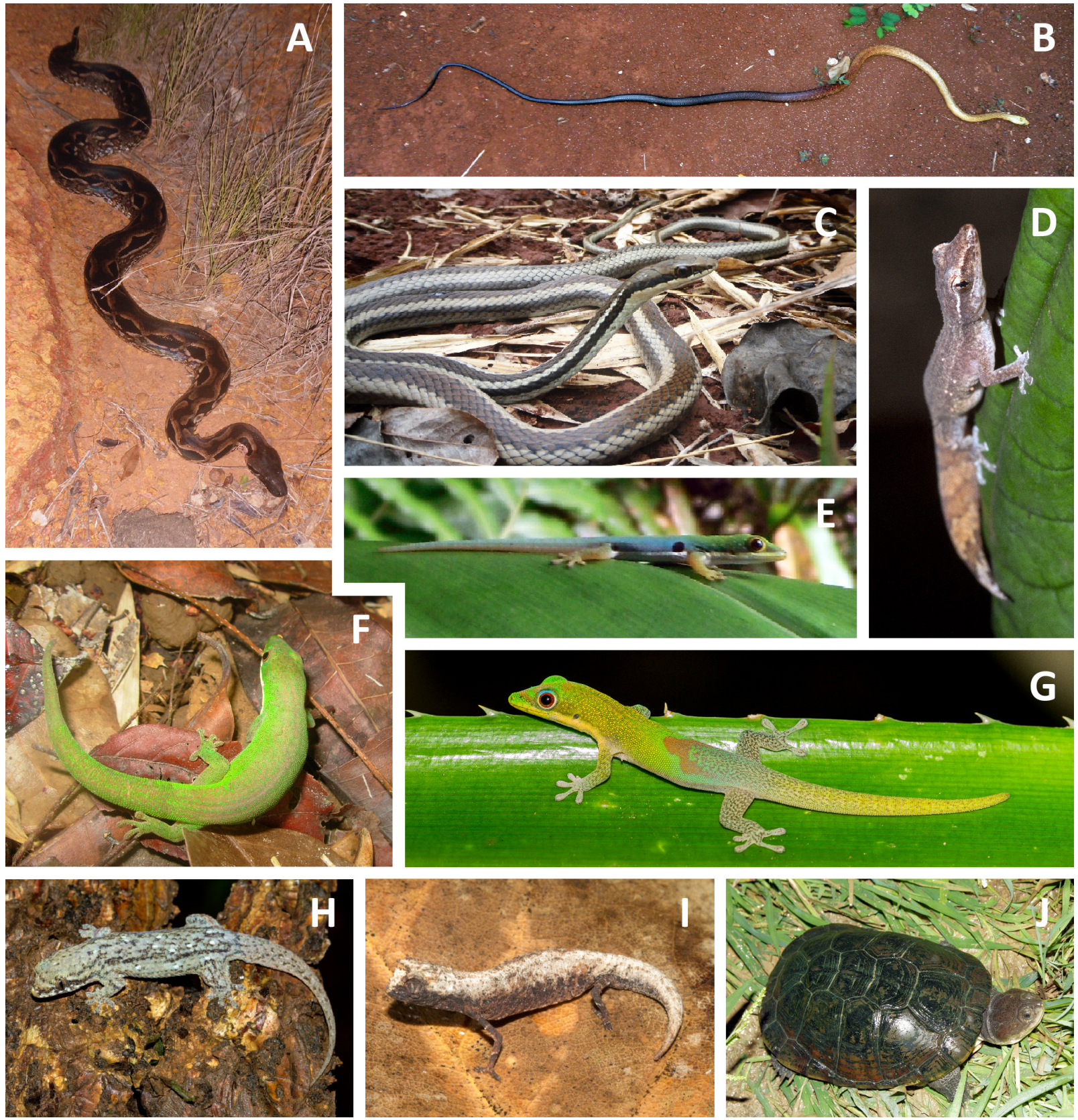

Figure 4. Reptile species documented for the first time from the Sahamalaza Peninsula during the survey period 2011-2013: A. Acrantophis madagascariensis from Berara Forest; B. Ithycyphus perineti from Ankarafa Forest; C. Dromicodryas bernieri from Ankarafa Forest; D. Ebenavia inunguis from Ankarafa Forest; E. Phelsuma sp. aff. quadriocellata from Ankarafa Forest; F. Phelsuma vanheygeni from Ankarafa Forest; G. Phelsuma laticauda from Ankarafa Forest; H. Geckolepis humbolti from Anketsakely; I. Brookesia minima from Ankarafa Forest; J. Pelomedusa subrufa from Betsimipoaka. Photos A-C, E-F by S. Penny, and D, G-J by G. M. Rosa. 
Concord, USA) at a 16-bit resolution and $16 \mathrm{kHz}$ sampling rate using two side-mounted SMX-II microphones. The digital recorder was placed one to two metres above the ground/water by securing it with bungee leads to deadwood or a protruding branch. Acoustic recordings were made between sunset and sunrise over 60 nights, when frog activity is greatest (Glaw and Vences, 2007). Continuous recordings split into sections of 120 minutes each were saved in the standard uncompressed .WAV format. Preceding analysis recordings were split using a custom-written MATLAB (The Mathworks, Natick, USA, V7.14.0.739) script into minute long segments to allow for more efficient analysis. Spectrograms were viewed individually as a dual channel output using Avisoft SASlab Pro (Berlin, Germany, V5.2.06); a Hamming window with FFT window size of 512, with $100 \%$ frame, and an intensity threshold of $50 \%$ were used to create spectrograms. Species were distinguished by matching their temporal and spectral patterns with that of known reference recordings (S. Penny) and an acoustic library of Malagasy frogs (Vences et al., 2006; Rosa et al., 2011). This was achieved by both ear and through taking parameter measurements with Avisoft SASLab Pro (Avisoft SASlab Pro; Berlin, Germany; V5.2.06).

\section{Results}

This survey increases the total number of amphibian and reptile species known from the Sahamalaza Peninsula to 20 and 43 respectively (Table 2). A total of 17 amphibian species and 38 reptile species were found during the current survey period; all were encountered during either opportunistic or transect searching, 14 of the amphibian species were also detected through automated acoustic recording (40122 minutes analysed) and one species of amphibian and three of reptile during pitfall trapping (840 pitfall trap days which yielded a capture rate of $1.12 \%$ ). Survey effort amounts to 84 days in Ankarafa and 16 days in Anabohazo, or 28 days if survey effort by Andreone et al. (2001) is included. The cumulative number of species detected rose quickly during the start of the survey period and then began to stabilise, with almost $82 \%$ of the species being found in the first 50 days of survey (Figure 2). After reaching a plateau, we observed again the discovery of new species during the last 13 days (Figure 2). This overall pattern is observed on both groups of species.

Six species of amphibians (Figure 3) and eleven reptiles (Figure 4) were documented for the first time from
Sahamalaza (Table 2), with two of these taxa qualifying as new candidate species. These are Boophis ankarafensis, already described previously as a direct result of this survey (Penny et al., 2014) and Stumpffia sp. aff. pygmaea Ca "Sahamalaza" (UCS) (Table 2 and S1).

Seven taxa are so far known exclusively from the peninsula: Boophis ankarafensis, Boophis tsilomaro, Cophyla berara, Platypelis sp., Rhombophryne sp., Stumpffia sp. aff. pygmaea Ca "Sahamalaza" and Pseudoacontias menamainty; although also Lygodactylus tolampyae show a distinct genetic distance from the other known localitity from where genetic data are available (12\% uncorrected pairwise genetic distance at $16 \mathrm{~S}$ fragment between the population from Sahamalaza and Ankarafantsika) and future taxonomic revisions of this genus might confirm this record as a further candidate new species. There were several species previously recorded from Sahamalaza that were not detected during this last survey: three amphibians (Laliostoma labrosum, Platypelis sp. and Rhombophryne sp.) and five reptiles (Alluaudina bellyi, Ithycyphus miniatus, Paracontias hildebrandti, Pseudoacontias menamainty and Sanzinia madagascariensis) (see Table 2).

Nine of the species in our survey are treated as synonymous with those identified by Andreone et al. (2001), these are: Boophis tsilomaro (with Boophis albilabris), Cophyla berara (with Cophyla sp. 12), Stumpffia gimmeli (with Stumpffia cf. gimmeli), Flexiseps tanysoma (with Amphiglossus sp.), Phelsuma kochi (with Phelsuma madagascariensis), Pseudoacontias menamainty (with Pseudoacontias n. sp.), Blaesodactylus ambonihazo (with Blaesodactylus sakalava), Hemidactylus mercatorius (with H. cf.frenatus) and Lycodryas granuliceps (with L. pseudogranuliceps).

\section{Discussion}

\section{Survey effort}

Sampling techniques varied in efficiency. All species were detected during either opportunistic or transect searching and we consider this to be the most efficient survey methods. Pitfall trapping contributed the fewest number of specimens and proved ineffective at capturing amphibians, which are often proficient climbers or strong jumpers, enabling them to escape; the technique was more useful for the detection of fossorial reptile species, although all species we detected through pitfall trapping were also identified through other sam- 
pling techniques. However, in 2000 they enabled the discovery of the so far only known specimen of Pseudioacontias menamainty. Automated acoustic recording allowed for the rapid detection of amphibian species within a habitat; however as amphibian vocalisations are usually limited to the breeding period (Glaw and Vences, 2007) seasonally in-active species will have been missed. Existing audio reference recordings were required to correctly pair a vocalisation to a species during the analysis stage, thus automated acoustic recording must be used in tandem with other sampling methods to avoid missing the vocalisations of undescribed or unknown taxa. Thus, in our opinion this technique is more suited to habitat surveys for areas where most species are already known, rather than species inventories in limited surveyed areas. Despite providing no unique species records compared to the other techniques, unlike pitfall trapping, it required minimal field effort and enabled the expansion of monitoring to areas that may otherwise have been missed. We thus consider it to be a very useful tool for herpetological surveys.

\section{Species composition of the Sahamalaza Peninsula}

Although surveys always depend on contingency, it is likely that a significant proportion of Sahamalaza's amphibian and reptile fauna have been detected, when considering all herpetological survey work of the area. The detection of three new taxa (Boophis ankarafensis, Stumpffia sp. aff. pygmaea Ca "Sahamalaza", Geckolepis humbolti) unnoticed during the previous surveys, highlights the efficiency of using an integrative approach to species identification. The detection of several species (almost 20\%) in the final few weeks of the wet season, together with the detection of species missed during a previous survey by Andreone et al. (2001), highlights the necessity of conducting herpetological surveys over extended periods for areas with strong seasonal differences.

The presence of species representative of the drier biomes of West Madagascar (e.g. Aglyptodactylus securifer, Blommersia sp. Ca05 (UCS), Heterixalus luteostriatus, H. tricolor, Laliostoma labrosum, Blaesodactylus ambonihazo, Oplurus cuvieri, Madascincus stumpffi and Zonosaurus laticaudatus concurrent with species representative of the rainforests of Sambirano region to the north (e.g. Boophis brachychir, $B$. jaegeri, B. tephraeomystax, Gephyromantis pseudosasper, Mantella ebenaui, Mantidactylus ulcerosus, Stumpffia gimmeli, Alluaudina bellyi, Brookesia stumpffi, B. minima, Ebenavia inunguis, Ithycyphus perineti, Phelsuma laticauda, P. vanheygeni, Paroedura oviceps, P. stumpffi, Uroplatus henkeli and $U$. ebenaui) confirms that Sahamalaza's intermediate climate supports a transitional fauna between these two biomes.

The two forests of Anabohazo and Ankarafa show broadly similar species compositions with a few notable differences (Table 2). Four amphibian and ten reptile species were recorded in Anabohazo Forest but not in Ankarafa, while two amphibian and eight reptile species were found in Ankarafa but not in Anabohazo. It is likely that some of these differences only reflect bias in survey effort between the two locations. For example, several of the Gekkonidae detected from Ankarafa and not in Anabohazo: Blaesodactylus ambonihazo, E. inunguis, Phelsuma sp. aff. quadriocellata and $P$. vanheygeni, were likely missed due to the shorter time spent surveying this area, coupled with their infrequent to rare encounter rates. On the other hand, the species recorded in Anabohazo but not in Ankarafa are prone to have been missed, due to the positive bias in the sampling period in Ankarafa. However, the two forests fragments differ in size, habitat quality and geography and so some differences in species composition might be due to this. The two fragments are separated from one another by around 20 $\mathrm{km}$ of savannah and scrubland, potentially isolating many of the forest-dependent species. The far-ranging calls of G. pseudoasper were extremely conspicuous throughout Anabohazo yet entirely absent from Ankarafa. This difference cannot be attributed to season as surveys in Ankarafa took place immediately before and after the sampling period in Anabohazo. Anabohazo marks the most southerly extent of this species range (Glaw and Vences, 2007) and it is possible that the climate or geography of Ankarafa make it unsuitable for G. pseudoasper. The recently described Boophis ankarafensis was only found along perennial lotic streams in Ankarafa, a hydrological feature that is entirely absent within Anabohazo, which may explain its potential absence from here. This factor likely accounts for the non record of the helmeted turtle Pelomedusa subrufa.

\section{Range extensions}

All species documented from Ankarafa Forest represent new records from this locality. Several species were recorded from Sahamalaza for the first time and represent important range extensions. For Boophis tsi- 
lomaro, Cophyla berara and Blaesodactylus ambonihazo we provide the first distribution record outside of their respective type localities. In the case of Boophis tsilomaro and Cophyla berara the range expension is still limited to the Sahamalaza Peninsula. Yet, it is worthnoting that in C. berara we observe a genetic distance of $1 \%$ between the two known populations of Berara and Ankarafa. The record of Blaesodactylus ambonihazo represents a significant increase in its distributional range (extended northward by over $200 \mathrm{~km}$; Bauer et al., 2011; Ikeuchi and Mori, 2014). The recent formal description of this species (Bauer et al., 2011), along with those of $B$. victori Ineich et al., 2016 and $B$. microtuberculatus Jono et al., 2015, together with the confirmed sympatry of $B$. victori with $B$. sakalava (Grandidier, 1867), and of B. microtuberculatus with B. boivini Duméril, 1856 (Jono et al., 2015; Ineich et al., 2016), further highlights the importance of applying a taxonomically integrative approach, and the need to reassess previously known localities and providing new genetic data. The distribution of B. ambonihazo may extend to other dry forests fragments in northwestern Madagascar, but due to the genera's apparent requirements for areas of relatively low disturbance containing at least some large trees, its distribution is likely to be severely fragmented (Ineich et al., 2016).

The species Acrantophis madagascariensis and Crocodylus niloticus are reported from Sahamalaza for the first time. Unfortunately, Acrantophis madagascariensis was only recorded in the 2011-2012 expedition and no genetic data are available on this record. Only a single specimen of $C$. niloticus was sighted, of which the tail-end was seen slipping into the water of the Vavan'aneno River in Antafiabe; local people attested the presence of multiple specimens within the area but note that the largest individuals have been lost to hunting. The presence of the snake Ithycyphus perineti, gecko Ebenavia inunguis, chameleon Brookesia minima and treefrog Boophys brachychir within Sahamalaza extend their ranges over $100 \mathrm{~km}$ south along Madagascar's west coast from Nosy Be (Glaw and Vences, 2007). The population of the Ebenavia inunguis sampled in Ankarafa belong to the Clade $\mathrm{Cb}$ (sensu Hawlitschek et al., 2017) as the popuation from Nosy Be, that is the type locality of this taxon. These two populations have a genetic distance of $4 \%$ at the analysed COI fragment, and thus far this represent the only other record for this taxon outside of Nosy Be. Brookesia minima was known at least from Nosy Be and Manongarivo and the population sampled in this study has a genetic distance of $5 \%$ with the population from Manongarivo. Similarily, B. brachychir was already reported for Nosy Be, Manongarivo, Forêt d'Ambre and near Antsiranana. This record thus represent the southern most new distribution.

The presence of Heterixalus tricolor confirms the species' distribution between Nosy Be and Ankarafantsika (Glaw and Vences, 2007). The presence of the turtle Pelomedusa subrufa extends their range over $200 \mathrm{~km}$ northeast of a record from Mahajanga (Iverson, 1992; Glaw and Vences, 2007; Petzold et al., 2014), placing this population at the northern edge of their projected distribution (Boycott and Bourquin, 2008), although no genetic distance was observed between the $P$. subrufa sequences of the newly reported population and the available sequences in Genbank.

We treated Phelsuma kochi as synonymous with $P$. madagascariensis, recorded by Andreone et al. (2001) following molecular identification; however, a photo from the earlier survey period resembles $P$. grandis Gray, 1870, known from the Sambirano region to the north, and it remains possible that the species occurs in sympatry with $P$. kochi. The occurance of $P$. kochi extends their range over $200 \mathrm{~km}$ northeast of Ankarafantsika (Mori et al., 2006; Glaw et al., 2011) and the genetic distance between the population from Sahamalaza and Tsingy de Bemaraha is of $7 \%$ at the analysed COI fragment.

This survey documents the first record of Phelsuma laticauda from Sahamalaza, a species known from a number of locations across northern Madagascar (Gelach et al., 2011). The presence of Phelsuma vanheygeni increases their known range of about $50 \mathrm{~km}$ south beyond the Ampasindava peninsula, where the species was classified as Endangered due to their restricted range (Randrianantoandro et al., 2011). The presence of Phelsuma sp. aff. quadriocellata marks their only documented occurrence in north western Madagascar and a significant distance from the populations known from Eastern Madagascar (Glaw and Vences, 2007). Furthermore, individual's from Sahamalaza occurred at heights of 150-170 m asl, significantly lower than the mid-elevation areas of 720-1350 $\mathrm{m}$ asl where the species is generally reported in the East (Glaw and Vences, 2011). The individuals encountered were found residing in Pandanus screw palms, a trait shared with Phelsuma quadriocellata (Peters 1883), however it is unknown whether they are truly conspecific as genetic data are not available. Their rare encounter rate from Sahamalaza may mean they have been missed by other surveys and indicate the species occurs between these distant sites; alternatively, they 
may belong to a different $P$. species. The species may be synonymous with Phelsuma cf. quadriocellata reported from Nosy Be (Andreone et al., 2003). The record of Madascincus stumpffi in Sahamalaza, similar with the record from Marojejy, mark the southernost distributional record for the species, but the population from Sahamalaza have a genetic distrace of $9 \%$ at the analysed COI fragment if compared with the population of M. stumpffi of Forest d'Ambre.

The presence of the frog Blommersia sp. Ca05 (UCS) marks a range increase of over $300 \mathrm{~km}$ beyond Tsingy de Bemaraha. Populations are also known from Isalo, Makay and Kirindy, while recent records of a Blommersia species from Mariarano and Mitsinjo near the Besiboka delta may also be attributed to $B$. sp. Ca05 (Rakotoarison et al., 2015), potentially indicating the species is widely distributed along the Madagascar's west coast. Finally, we report a new record of the recently resurrected Geckolepis humbolti which, in Madagascar, was until now known only in the Tsingy de Bemaraha. The newly reported population of Geckolepis humbolti from Sahamalaza has a genetic distance of $8-9 \%$ with the populations from the Comoros and Mayotte.

\section{Endemicity patterns}

Two new species of amphibians (B. ankarafensis and Stumpffia sp. aff. pygmaea Ca "Sahamalaza" (UCS)) identified in this survey and four species identified in prior surveys (Boophis tsilomaro, Cophyla berara, Rhombophryne sp. and Platypelis sp.) may represent local endemics as they have not been detected in other surveys of Northwest Madagascar (e.g. Nosy Be, Manongarivo, Tsaratanana, Benavony), in some cases, despite their prominent and distinctive calls (Vences et al., 2005b, 2010b; Glaw and Vences, 2007). The failure to detect neither Platypelis sp. nor Rhombophryne sp. during the most recent surveys mean that further effort should be invested in the area, as representatives of these genera are sometimes very difficult to detect. The population of Lygodactylus tolampyae from Sahamalaza was already known, however this population has a high genetic divergence with the other population of this species for which genetic data are available. A more in depth taxonomic revision of this genus is needed to apply this name to a specific taxon, until then it will not be possible to assess the taxonomic identification of the Lygodactylus tolampyae population from Sahamalaza. However, this might represent a new microendemic species of retile along with the pre- viously identified and highly elusive skink Pseudoacontias menamainty. All this points towards the Sahamalaza peninsula being an important centre of microendemicity.

The new species of treefrog, Boophis ankarafensis, was described following the results of this survey (Penny et al., 2014). The species is only known from the banks of perennial streams in intact forest vegetation in Ankarafa Forest and has been classified as Critically Endangered on the IUCN Red List. The new candidate species, Stumpffia sp. aff. pygmaea $\mathrm{Ca}$ "Sahamalaza" (UCS), still awaits formal description but molecular data found only a 92-93\% match ( $p$-distance transformed into percent; at the analysed 16S fragment) with $S$. pygmaea and their taxonomic distinctness seems therefore to be granted. The species produces inconspicuous calls from within leaf-litter which are difficult to locate, thus the species may have been missed during surveys outside the peninsula. On the contary, this is such a small amphibian species that dispersal capacities might be very low. Our survey expands the range of Boophis tsilomaro beyond their type locality of Berara. The detection of B. tsilomaro from Anketsakely, a fragment of forest within Anabohazo, contributes only a marginal increase in range, and the species is confined to an area of less than 5 $\mathrm{km}^{2}$, qualifying it as Critically Endangered. The species' absence from Ankarafa Forest, the only other significant area of forest on the peninsula, reinforces the importance of protecting all remaining areas of natural habitat in Sahamalaza, as populations may be reliant on particular conditions.

This survey expands the range of Cophyla berara beyond their type locality of Berara: a fragment of primary forest in Anabohazo (Vences et al., 2005b). We document the species throughout the fragments of Ankarafa Forest, the surroundings of Antafiabe village and the fragment of Anketsakely in Anabohazo Forest. These locations are no greater than $20 \mathrm{~km}$ distant from the type locality, yet mark an important extension to the distribution of this species and indicate multiple populations exist. Furthermore, C. berara were found in abundance in low quality secondary forest, a habitat common throughout the peninsula. Secondary tracts of regenerating forest are one of the most common forest types in Ankarafa and past land clearances have created a matrix of interlinked forest fragments surrounded by large thickets of bamboo. $C$. berara were extremely abundant in these forest edge habitats, and in interior sections where bamboo were present, a habit also reported in C. maharipeo (Rakotoarison et al., 
2015). This association is likely due to their breeding habitat of laying spawn inside water-filled segments of bamboo. The species was detected in all surveyed forest fragments, including isolated sections of heavily degraded forest that had experienced recent burning; callers were also found perched on scorched leaves and branches. Thus, this species seems to be adapted to disturbed forest, and is less likely to experience severe decline in the immediate future. However, its long-term viability in these small isolated forest fragments is unknown and even with these new range extensions, it is still known from just three areas within the Sahamalaza Peninsula, which itself totals around 26000 hectares. There appears to be limited gene flow between populations in Ankarafa and Anababohazo and molecular analyses show they have already slightly diverged, with two fix substitutions at the analysed mitochondrial 16S fragment (Penny et al., 2016). Although the species appears relatively well adapted to disturbed forest, it is still a forest-dependent species and at risk from future habitat destruction.

\section{Threats and conservation}

Forest on the peninsula continues to be exploited by the human populations. Fire has already destroyed Analavory Forest, leaving Ankarafa and Anabohazo the largest areas of intact forest in Sahamalaza. These two locations are subject to high levels of forest clearance to make way for crop cultivation and pastureland (Penny et al., 2014, 2016). Furthermore, fires lit in the dry season to rejuvenate grazing land frequently spread out of control and burn adjacent areas of intact forest. Selective logging of tropical hardwoods and small-scale quarrying were also observed in Anabohazo Forest, although currently this is still the more intact of the two remaining forests. If actions, such as those outlined by a recently published conservation action plan on the amphibians of Sahamalaza (Penny et al., 2016) are not promptly implemented, then all the peninsula's forest dwelling herpetofauna will suffer serious population declines and the local endemics will be pushed towards extinction.

\section{Acknowledgments}

This project was funded by the European Association of Zoos and Aquaria (EAZA). Our thanks go to the Malagasy authorities for granting research and export permits, to the Association Europeenne pour l'Etude et la Conservation des Lemuriens
(AEECL) for granting us the use of their research station, to Madagascar Institut pour la Conservation des Ecosystèmes Tropicaux ou (MICET) for logistical help and to Madagascar National Parks Association (MNP) for granting us access to the Park. Particular thanks go to our local Malagsy assistants: Fan, Loricia, Marlene and Regis, who made our time in the field possible. The work of AC is supported by the Portuguese National Funds through FCT - Foundation for Science and Technology under the IF/00209/2014/CP1256/CT0011 Exploratory Research Project and the Investigador FCT (IF) grant (IF/00209/2014). G. M. Rosa was funded by FCT through the Doctoral Programme (SFRH/BD/69194/2010).

\section{References}

AmphibiaWeb. 2017. <https://amphibiaweb.org> University of California, Berkeley, CA, USA. Accessed 22 Nov 2017.

Andreone F, Cadle JE, Cox N, Nussbaum RA, Raxworthy CJ, Stuart SN, Vallan D, Vences M. 2005. Species review of amphibian extinction risks in Madagascar: conclusions from the Global Amphibian Assessment. Conservation Biology 19: 1790-1802.

Andreone F, Carpenter AI, Copsey J, Crottini A, Garcia, G, Jenkins RKB, Köhler J, Rabibisoa NHC, Randriamahazo H, Raxworthy CJ. 2012. Saving the diverse Malagasy amphibian fauna: Where are we four years after implementation of the Sahonagasy Action Plan? Alytes 29: 44-58.

Andreone F, Rabibisoa N, Randrianantoandro C, Crottini A, Edmonds D, Kraus F, Lewis JP, Moore M, Rabemananjara FCE, Rabemanantsoa JC, Vences M. 2014. Madagascar: Risk review is under way for invasive toad. Nature 512: 253-253.

Andreone F, Rosa GM, Noël J, Crottini A, Vences M, Raxworthy CJ. 2010. Living within fallen palm leaves: the discovery of an unknown Blommersia (Mantellidae: Anura) reveals a new reproductive strategy in the amphibians of Madagascar. Naturwissenschaften 97: 525-543.

Andreone F, Vences M, Randrianirina JE. 2001. Patterns of amphibian and reptile diversity at Berara Forest (Sahamalaza Peninsula), NW Madagascar. Italian Journal of Zoology 68: 235-241.

Arévalo E, Davis SK, Sites J. 1994. Mitochondrial DNA sequence divergence and phylogenetic relationships among eight chromosome races of the Sceloporus grammicus complex (Phrynosomatidae) in Central Mexico. Systematic Biology 43: 387-418.

Bauer AM, Glaw F, Gehring PS, Vences M. 2011. New species of Blaesodactylus (Squamata: Gekkonidae) from Ankarafantsika National Park in north-western Madagascar. Zootaxa 2942: 57-68.

Birkinshaw CR. 2004. Priority areas for plant conservation. Ravintsara 2: 14-15.

Bletz MC, Rosa GM, Andreone F, Courtois EA, Schmeller DS, Rabibisoa NH, Rabemananjara FCE, Raharivololoniaina L, Vences M, Weldon C, Edmonds D, Raxworthy CJ, Harris RN, Fisher MC, Crottini A. 2015a. Widespread presence of the pathogenic fungus Batrachochytrium dendrobatidis in wild amphibian communities in Madagascar. Scientific Reports 5: 8633.

Bletz MC, Rosa GM, Andreone F, Courtois EA, Schmeller DS, 
Rabibisoa NH, Rabemananjara FCE, Raharivololoniaina L, Vences M, Weldon C, Edmonds D, Raxworthy CJ, Harris RN, Fisher MC, Crottini A. 2015b. Consistency of published results on the pathogen Batrachochytrium dendrobatidis in Madagascar: Formal comment on Kolby et al. Rapid Response to Evaluate the Presence of Amphibian Chytrid Fungus (Batrachochytrium dendrobatidis) and Ranavirus in Wild Amphibian Populations in Madagascar PLoS ONE 10: e0135900.

Böhm M, Collen B, Baillie JEM, Bowles P, Chanson J, Cox N, et al. 2013. The conservation status of the world's reptiles. Biological Conservation 157: 372-385.

Bora P, Ramilijaona O, Raminosoa N, Vences M. 2011. A new species of Mantidactylus (subgenus Chonomantis) from Ranomafana National Park, eastern Madagascar (Amphibia, Anura, Mantellidae). Zootaxa 2772: 52-60.

Bora P, Randrianantoandro JC, Randrianavelona R, Hantalalaina EF, Andriantsimanarilafy RR, Rakotondravony D, Ramilijaona OR, Vences M, Jenkins RK, Glaw F, Koehler J. 2010. Amphibians and reptiles of the Tsingy de Bemaraha Plateau, Western Madagascar: Checklist, biogeography and conservation. Herpetological Conservation and Biology 5: 111-125.

Boycott RC, Bourquin O. 2008. Pelomedusa subrufa (Lacépède 1788) - helmeted turtle, helmeted terrapin. In: Rhodin AGJ, Pritchard PCH, van Dijk PP, Saumure RA, Buhlmann KA, Iverson JB, eds. Conservation Biology of Freshwater Turtles and Tortoises: a compilation project of the IUCN/SSC Tortoise and Freshwater Turtle Specialist Group. Chelonian Research Monographs 5: 007.1-007.6.

Brown JL, Sillero N, Glaw F, Bora P, Vieites DR, Vences M. 2016. Spatial biodiversity patterns of Madagascar's amphibians and reptiles. PLoS ONE 11: e0144076.

Bruford MW, Hanotte O, Brookfield JFY, Burke T. 1992. Singlelocus and multilocus DNA fingerprinting: Oxford: IRL Press.

Crottini A, Andreone F, Edmonds, D, Hansen C M, Lewis JP, Rabemanantsoa JC, Moore M, Kraus F, Vences M, Rabemananjara FCE, Randrianantoandro C. 2014. A new challenge for amphibian conservation in Madagascar: the invasion of Duttaphrynus melanostictus in Toamasina province. FrogLog 111: 46-47.

Crottini A, Harris DJ, Miralles A, Glaw F, Jenkins RK, Randrianantoandro JC, Bauer AM, Vences M. 2015. Morphology and molecules reveal two new species of the poorly studied gecko genus Paragehyra (Squamata: Gekkonidae) from Madagascar. Organisms Diversity \& Evolution 15: 175-98.

Crottini A, Gehring P-S, Glaw F, Harris DJ, Lima A, Vences M. 2011. Deciphering the cryptic species diversity of dull-coloured day geckos Phelsuma (Squamata: Gekkonidae) from Madagascar, with description of a new species. Zootaxa 2982: 40-48

Crottini A, Madsen O, Poux C, Strauß A, Vieites DR, Vences M. 2012. Vertebrate time-tree elucidates the biogeographic pattern of a major biotic change around the $\mathrm{K}-\mathrm{T}$ boundary in Madagascar. Proceedings of the National Academy of Sciences 109: 5358-5363.

D'Cruze NC, Green KE, Robinson JE, Gardner CJ. 2006. A rapid assessment of the amphibians and reptiles of an unprotected area of dry deciduous forest in north Madagascar. Herpetological Bulletin 96: 17-25.
Elmqvist T, Pyykönen M, Tengö M, Rakotondrasoa F, Rabakonandrianina E, Radimilahy C. 2007. Patterns of loss and regeneration of tropical dry forest in Madagascar: the social institutional context. PLOS ONE 2: e402.

Florio A, Ingram C, Rakotondravony H, Louis E, Raxworthy C. 2012. Detecting cryptic speciation in the widespread and morphologically conservative carpet chameleon (Furcifer lateralis) of Madagascar. Journal of Evolutionary Biology 25: 1399-1414.

Food and Agriculture Organization of the United Nations (FAO). 2015. Global forest resources assessment. Main report. Rome: FAO.

Fouquet A, Gilles A, Vences M, Marty C, Blanc M, Gemmell NJ. 2007. Underestimation of species richness in Neotropical frogs revealed by mtDNA analyses. PLoS ONE, 2: e1109.

Gehring P-S, Ratsoavina FM, Vences M, Glaw F. 2011. Calumma vohibola, a new chameleon species (Squamata: Chamaeleonidae) from the littoral forests of eastern Madagascar. African Journal of Herpetology 60: 130-154.

Gerlach J, Ineich I, Vences M. 2011. Phelsuma laticauda. The IUCN Red List of Threatened Species e.T61433A12483895 http://dx.doi.org/10.2305/IUCN.UK.2011-2.RLTS. T61433A12483895.en

Glaw F, Vences M. 2007. A field guide to the amphibians and reptiles of Madagascar. Third edition. Cologne: Vences \& Glaw Verlag.

Glaw F, Köhler J, Townsend TM, Vences M. 2012. Rivalling the world's smallest reptiles: discovery of miniaturized and microendemic new species of leaf chameleons (Brookesia) from northern Madagascar. PLoS ONE 7: e31314.

Glaw F, Koehler J, de la Riva I, Vieites D, Vences M. 2010. Integrative taxonomy of Malagasy treefrogs: combination of molecular genetics, bioacoustics and comparative morphology reveals twelve additional species of Boophis. Zootaxa 2383: $1-82$.

Glaw F, Kucharzewski C, Nagy ZT, Hawlitschek O, Vences, M. 2014. New insights into the systematics and molecular phylogeny of the Malagasy snake genus Liopholidophis suggest at least one rapid reversal of extreme sexual dimorphism in tail length. Organisms Diversity \& Evolution 14: 121-132.

Glaw F, Rakotondrazafy NA, Rabibisoa N, Ratsoavina F. 2011. Phelsuma kochi. The IUCN Red List of Threatened Species e.T193491A8863846. http://dx.doi.org/10.2305/IUCN. UK.2011-2.RLTS.T193491A8863846.en

Glos J, Dausmann KH, Linsenmair KE. 2008. Modelling the habitat use of Aglyptodactylus laticeps, an endangered dryforest frog from Western Madagascar. In: Andreone F, ed. A Conservation Strategy for the Amphibians of Madagascar. Monografie del Museo Regionale di Scienze Naturali di Torino, XLV, Museo Regionale di Scienze Naturali, Turin, 45: 125-42.

Hall TA. 1999. BioEdit: A user-friendly biological sequence alignment editor and analysis program for Windows 95/98/ NT. Nucleic Acids Symposium Series 41: 95-98.

Hawlitschek O, Toussaint EFA, Gehring P-S, Ratsoavina FM, Cole N, Crottini A, Nopper J, Lam AW, Vences M, Glaw F. 2017. Gecko phylogeography in the Western Indian Ocean region: The oldest clade of Ebenavia inunguis lives on the youngest island. Journal of Biogeography 44: 409-420.

Heinermann J, Rodríguez A, Segev O, Edmonds D, Dolch R, Vences M. 2015. Year-round activity patterns in a hyperdi- 
verse community of rainforest amphibians in Madagascar. Journal of Natural History 49: 2213-2231.

Huey RB, Deutsch CA, Tewksbury JJ, Vitt LJ, Hertz PE, Pérez HJÁ, Garland T. 2009. Why tropical forest lizards are vulnerable to climate warming. Proceedings of the Royal Society of London B: Biological Sciences 276: 1939-1948.

Ikeuchi I, Mori A. 2014. Natural history of a Madagascan gecko Blaesodactylus ambonihazo in a dry deciduous forest. Current Herpetology 33:161-170.

Ineich I, Glaw F, Vences M. 2016. A new species of Blaesodactylus (Squamata: Gekkonidae) from Tsingy limestone outcrops in Namoroka National Park, north-western Madagascar. Zootaxa 4109: 523-541.

Iverson J. 1992. A revised checklist with distribution maps ofthe turtles of the World. Richmond, IN: Privately published.

Irwin MT, Wright PC, Birkinshaw C, Fisher BL, Gardner CJ, Glos J, Goodman SM, Loiselle P, Rabeson P, Raharison J-L. 2010. Patterns of species change in anthropogenically disturbed forests of Madagascar. Biological Conservation 143 2351-2362.

Janzen DH. 1988. Tropical dry forests. The most endangered major tropical ecosystem (Vol. 3). Washington DC: National Academy Press.

Jenkins RK, Tognelli MF, Bowles P, Cox N, Brown JL, Chan L, Andreone F, Andriamazava A, Andriantsimanarilafy RR, Anjeriniaina M, Bora P. 2014. Extinction risks and the conservation of Madagascar's reptiles. PLOS ONE 9: e100173.

Jono T, Bauer AM, Brennan I, Mori A. 2015. New species of Blaesodactylus (Squamata: Gekkonidae) from Tsingy karstic outcrops in Ankarana National Park, northern Madagascar. Zootaxa 3980: 406-416.

Kolby JE. 2014. Ecology: Stop Madagascar's toad invasion now. Nature 509: 563-563.

Kolby JE, Smith KM, Ramirez SD, Rabemananjara F, Pessier AP, Brunner JL, Goldberg CS, Berger L, Skerratt LF. 2015. Rapid response to evaluate the presence of amphibian chytrid fungus (Batrachochytrium dendrobatidis) and Ranavirus in wild amphibian populations in Madagascar. PLOS ONE 10: e0125330.

Köhler J, Glaw F, Pabijan M, Vences, M. 2015. Integrative taxonomic revision of mantellid frogs of the genus Aglyptodactylus (Anura: Mantellidae). Zootaxa 4006: 401-438.

Leaché AD, Reeder TW. 2002. Molecular systematics of the eastern fence lizard (Sceloporus undulatus): a comparison of parsimony, likelihood, and Bayesian approaches. Systematics Biology 51: 44-68.

Lehtinen RM, Glaw F, Vences M. 2011. Two new plant-breeding frog species (Anura: Mantellidae, Guibemantis) from southeastern Madagascar. Herpetological Journal 21: 95-112.

Macey JR, Larson A, Ananjeva NB, Fang Z, Papenfuss TJ. 1997. Two novel gene orders and the role of light-strand replication in rearrangement of the vertebrate mitochondrial genome. Molecular Biology and Evolution 14: 91-104.

Macey JR, Schulte II JA, Larson A, Ananjeva NB, Wang Y, Pethiyagoda R, Rastegar-Pouyani N, Papenfuss TJ. 2000. Evaluating trans-Tethys migration: an example using acrodont lizard phylogenetics. Systematic Biology 49: 233-256.

Mercurio V, Aprea G, Crottini A, Mattioli F, Randrianirina JE, Razafindrabe TJ, Andreone, F. 2008. The amphibians of Isalo Massif, southern-central Madagascar: high frog diversity in an apparently hostile dry habitat. In: Andreone F, ed. A
Conservation Strategy for the Amphibians of Madagascar. Monografie del Museo Regionale di Scienze Naturali di Torino, XLV, Museo Regionale di Scienze Naturali, Turin, 45: 143-196.

Meyer CP, Geller JB, Paulay G. 2005. Fine scale endemism on coral reefs: Archipelagic differentiation in turbinid gastropods. Evolution 59: 113-125.

Miralles A, Glaw F, Ratsoavina FM, Vences M. 2015. A likely microendemic new species of terrestrial iguana, genus Chalarodon, from Madagascar. Zootaxa 3946: 201-220.

Miralles A, Koehler J, Glaw F, Vences M. 2011. A molecular phylogeny of the "Madascincus polleni species complex", with description of a new species of scincid lizard from the coastal dune area of northern Madagascar. Zootaxa 2876: 1-16.

Miralles A, Jono T, Mori A, Gandola R, Erens J, Köhler J, Glaw F, Vences M. 2016. A new perspective on the reduction of cephalic scales in fossorial legless skinks (Squamata, Scincidae). Zoologica Scripta 45: 380-393.

Monastersky R. 2014. Biodiversity: Life-a status report. Nature 516: 158-161.

Mori A, Ikeuchi I, Hasegawa M. 2006. Herpetofauna of Ampijoroa, Ankarafantsika strict nature reserve, a dry forest in northwestern Madagascar. Herpetological Natural History 10: 31-60.

Nagy ZT, Sonet G, Glaw F, Vences, M. 2012. First large-scale DNA barcoding assessment of reptiles in the biodiversity hotspot of Madagascar, based on newly designed COI primers. PLoS ONE 7: e34506.

Palumbi S, Martin A, Romano S, McMillan WO, Stice L, Grabowski G. 1991. The simple fool's guide to PCR. Honolulu: Department of Zoology.

Penny SG, Andreone F, Crottini A, Holderied MW, Rakotozafy LS, Schwitzer C, Rosa, GM. 2014. A new species of the Boophis rappiodes group (Anura, Mantellidae) from the Sahamalaza Peninsula, northwest Madagascar, with acoustic monitoring of its nocturnal calling activity. ZooKeys 435: 111-132.

Penny SG, Andreone F, Crottini A, Holderied MW, Rosa G, Schwitzer C. 2016. The amphibians of the Sahamalaza Peninsula, northwest Madagascar - actions for their conservation. Bristol, UK: Bristol Zoological Society.

Perl RB, Nagy ZT, Sonet G, Glaw F, Wollenberg KC, Vences M. 2014. DNA barcoding Madagascar's amphibian fauna. Amphibia-Reptilia 35: 197-206.

Petzold A, Vargas-Ramirez M, Kehlmaier C, Vamberger M, Branch WR, Du Preez L, Hofmeyr MD, Meyer L, Schleicher A, Široký P, Fritz U. 2014. A revision of African helmeted terrapins (Testudines: Pelomedusidae: Pelomedusa), with descriptions of six new species. Zootaxa 3795:523-548.

Pons P, Rakotobearison G, Wendenburg C. 2003. Immediate effects of a fire on birds and vegetation at Ankarafantsika Strict Nature Reserve, NW Madagascar. Ostrich-Journal of African Ornithology 74: 146-148.

Rakotoarison A, Crottini A, Mueller J, Roedel M-O, Glaw F, Vences, M. 2015. Revision and phylogeny of narrow-mouthed treefrogs (Cophyla) from northern Madagascar: integration of molecular, osteological, and bioacoustic data reveals three new species. Zootaxa 3937: 61-89.

Rakotoarison A, Scherz MD, Glaw F, Köhler J, Andreone F, Franzen M, Glos J, Hawlitschek O, Jono T, Mori A, Ndriant- 
soa SH, Rasoamampionona Raminosoa N, Riemann JC, Rödel M-O, Rosa GM, Vieites DR, Crottini A, Vences M. 2017. Describing the smaller majority: Integrative taxonomy reveals twenty-six new species of tiny microhylid frogs (genus Stumpffia) from Madagascar. Vertebrate Zoology 67(3): 271-398.

Randrianantoandro JC, Raxworthy CJ, Ratsoavina F, Glaw F, Rabibisoa N. 2011. Phelsuma vanheygeni. The IUCN Red List of Threatened Species eT172776A6915653 http://dxdoiorg/102305/IUCNUK2011-2RLTST172776A6915653en

Raselimanana AP. 2003. Gerrhosauridae, plated lizards. Chicago: The University of Chicago Press.

Raselimanana AP. 2008. Herpétofaune des forêts sèches malgaches. Malagasy Nature 1: 46-75.

Raselimanana AP, Nussbaum RA, Raxworthy CJ. 2006. Observations and re-description of Zonosaurus boettgeri Steindachner 1891 and description of a second new species of long-tailed Zonosaurus from western Madagascar. Occasional papers of the Museum of Zoology, University of Michigan 739: 1-16.

Raselimanana AP, Raxworthy CJ, Nussbaum RA. 2000. A revision of dwarf Zonosaurus Boulenger (Reptilia: Squamata: Cordylidae) from Madagascar, including descriptions of three new species. Scientific Papers, Natural History Museum, University of Kansas: 1-16.

Raselimanana AP, Raxworthy CJ, Andreone F, Glaw F, Vences M. 2014. An enigmatic new Scaphiophryne toadlet from the rainforests of north-eastern Madagascar (Amphibia: Microhylidae). Vertebrate Zoology 64: 95-102.

Ratsoavina FM, Louis Jr EE, Crottini A, Randrianiaina RD, Glaw F, Vences M. 2011. A new leaf tailed gecko species from northern Madagascar with a preliminary assessment of molecular and morphological variability in the Uroplatus ebenaui group. Zootaxa 3022: 39-57.

Raxworthy CJ, Pearson, RG Rabibisoa N, Rakotondrazafy AM, Ramanamanjato JB, Raselimanana AP, Wu S, Nussbaum RA, Stone DA. 2008. Extinction vulnerability of tropical montane endemism from warming and upslope displacement: a preliminary appraisal for the highest massif in Madagascar. Global Change Biology 14: 1703-1720.

Riemann JC, Ndriantsoa, SH Raminosoa NR, Rödel MO, Glos J. 2015. The value of forest fragments for maintaining amphibian diversity in Madagascar. Biological Conservation 191: 707-715.

International Commission on Zoological Nomenclature. 1999. International Code of Zoological Nomenclature, fourth edition. Ride WDL, Cogger HG, Dupuis C, Kraus O, Minelli A, Thompson FC, Tubbs PK (eds.). Adopted by the International Union of Biological Sciences. London: International Trust for Zoological Nomenclature.

Roelants K, Gower DJ, Wilkinson M, Loader SP, Biju SD, Guillaume K, Moriau L, Bossuyt F. 2007. Global patterns of diversification in the history of modern amphibians. Proceedings of the National Academy of Sciences 104: 887-892.

Rosa GM, Andreone F, Crottini A, Hauswaldt JS, Noël J, Rabibisoa NH, Randriambahiniarime MO, Rebelo R, Raxworthy CJ. 2012. The amphibians of the relict Betampona low-elevation rainforest, eastern Madagascar: an application of the integrative taxonomy approach to biodiversity assessments. Biodiversity and Conservation 21: 1531-1559.

Rosa GM, Márquez R, Andreone F. 2011. The astonishing calls of the frogs of Betampona [audio CD \& booklet]. Turin: Museo Regionale di Scienze Naturali di Torino.

Rosa GM, Crottini A, Noël J, Rabibisoa N, Raxworthy CJ, Andreone F. 2014. A new phytotelmic species of Platypelis (Microhylidae: Cophylinae) from the Betampona Reserve, eastern Madagascar. Salamandra 50: 201-214.

Samonds KE, Godfrey LR, Ali JR, Goodman SM, Vences M, Sutherland MR, Irwin MT, Krause DW. 2012. Spatial and temporal arrival patterns of Madagascar's vertebrate fauna explained by distance, ocean currents, and ancestor type. Proceedings of the National Academy of Sciences 109: 53525357.

Scherz MD, Glaw F, Vences M, Andreone F, Crottini A. 2016. Two new species of terrestrial microhylid frogs (Microhylidae: Cophylinae: Rhombophryne) from northeastern Madagascar. Salamandra 52(2): 91-106.

Schmitz A, Brandley MC, Mausfeld P, Vences M, Glaw F, Nussbaum RA, Reeder TW. 2005. Opening the black box: phylogenetics and morphological evolution of the Malagasy fossorial lizards of the subfamily "Scincinae". Molecular Phylogenetics and Evolution 34: 118-133.

Schuurman D, Andreone F. 2010. Rampant logging, illegal collection and slash and burn agriculture driving Madagascar's rare frogs towards extinction. Wildlife Extra, 15 December 2010 (available from http://www.wildlifeextra.com/go/news/ madagascar-frogs.html\#cr)

Schwitzer C, Schwitzer N, Randriatahina GH, Rabarivola C, Kaumanns W. 2006. "Programme Sahamalaza": New perspectives for the in situ and ex situ study and conservation of the blue-eyed black lemur (Eulemur macaco flavifrons) in a fragmented habitat. Proceedings of the German-Malagasy Research Cooperation in Life and Earth Sciences 11: 135149.

Schwitzer N, Randriatahina GH, Kaumanns W, Hoffmeister D, Schwitzer C. 2007. Habitat utilization of blue-eyed black lemurs, Eulemur macaco flavifrons (Gray, 1867), in primary and altered forest fragments. Primate Conservation 22: 7987.

Schwitzer C, Mittermeier RA, Johnson SE, Donati G, Irwin M, Peacock H, Ratsimbazafy J, Razafindramanana J, Louis E, Chikhi L, Colquhoun IC, Tinsman J, Dolch R, LaFleur M, Nash S, Patel E, Randrianambinina B, Rasolofoharivelo T, Wright PC. 2014. Averting lemur extinctions amid Madagascar's political crisis. Science 343: 842-843.

Seiler M, Randriatahina GH, Schwitzer C. 2012. The rapid boost of forest destruction and poaching of lemurs inside the Sahamalaza - Îles Radama National Park. Lemur News 16: 28-30.

Sinervo B, Mendez-De-La-Cruz F, Miles DB, Heulin B, Bastiaans E, Villagrán-Santa Cruz M, Lara-Resendiz R, Martínez-Méndez N, Calderón-Espinosa ML, Meza-Lázaro RN, Gadsden H. 2010. Erosion of lizard diversity by climate change and altered thermal niches. Science 328: 894-899.

Sodhi NS, Bickford D, Diesmos AC, Lee TM, Koh LP, Brook BW, Sekercioglu CH, Bradshaw CJ. 2008. Measuring the meltdown: drivers of global amphibian extinction and decline. PLOS ONE 3: pe1636.

Smith AP. 1997. Deforestation, fragmentation, and reserve design in western Madagascar. In: Lawrence WF, Bierregaard Jr RO, eds. Tropical forest remnants: Ecology, management, and conservation of fragmented communities. Chicago, IL: The University of Chicago Press: 415-441. 
Stuart SN, Chanson JS, Cox NA, Young BE, Rodrigues ASL, Fischman DL, Waller RW. 2004. Status and trends of amphibian declines and extinctions worldwide. Science 306: 1783-1786.

Sussman RW, Rakotozafy A. 1994. Plant diversity and structural analysis of a tropical dry forest in southwestern Madagascar. Biotropica 26(3): 241-254.

Vences M, Andreone F, Glaw, F. 2005b. A new microhylid frog of the genus Cophyla from a transitional forest in northwestern Madagascar. African Zoology 40: 143-149.

Vences M, Glaw F, Márquez R. 2006. The calls of the frogs of Madagascar. 3 Audio CDs and Booklet. Barcelona: Alosa Fonozoo.

Vences M, Andreone F, Glos J, Glaw F. 2010b. Molecular and bioacoustic differentiation of Boophis occidentalis with description of a new treefrog from north-western Madagascar. Zootaxa 2544: 54-68.

Vences M, Glaw F, Köhler J, Wollenberg KC. 2010a. Molecular phylogeny, morphology and bioacoustics reveal five additional species of arboreal microhylid frogs of the genus Anodonthyla from Madagascar. Contributions to Zoology 79: 1-32.

Vences M, Thomas M, Bonett RM, Vieites DR. 2005a. Deciphering amphibian diversity through DNA barcoding: chances and challenges. Philosophical Transactions of the Royal Society B: Biological Sciences 360: 1859-1868.

Vences M, Brown JL, Lathrop A, Rosa GM, Cameron A, Crottini A, Dolch R, Edmonds D, Freeman K, Glaw F, Grismer LL, Litvinchuk S, Milne M, Moore M, Solofo JF, Noël J, Nguyen TQ, Ohler A, Randrianantoandro C, Raselimanana AP, Van Leeuwen P, Wogan GOU, Ziegler T, Andreone F, Murphy RW. 2017. Tracing a toad invasion: Lack of mitochondrial DNA variation, haplotype origins, and poten- tial distribution of introduced Duttaphrynus melanostictus in Madagascar. Amphibia-Reptilia 38: 197-207.

Vences M, Köhler J, Pabijan M, Bletz M, Gehring PS, Hawlitschek O, Rakotoarison A, Ratsoavina FM, Andreone F, Crottini A, Glaw F. 2017. Taxonomy and geographic distribution of Malagasy frogs of the Gephyromantis asper clade, with description of a new subgenus and revalidation of $G e$ phyromantis ceratophrys. Salamandra 53: 77-98.

Vieites DR, Wollenberg KC, Andreone F, Köhler J, Glaw F, Vences M. 2009. Vast underestimation of Madagascar's biodiversity evidenced by an integrative amphibian inventory. Proceedings of the National Academy of Sciences 106: 8267-8272.

Volampeno, MSN. 2009. Reproductive behaviour and habitat use in the blue-eyed black lemur (Eulemur flavifrons, Gray, 1867) at the Sahamalaza Peninsula, National Park Madagascar. (PhD thesis), University of KwaZulu-Natal, Pietermaritzburg.

Volampeno MSN, Masters JC, Downs CT. 2011. Life history traits, maternal behavior and infant development of blueeyed black lemurs (Eulemur flavifrons). American Journal of Primatology 73: 474-484.

Walls SC, Barichivich WJ, Brown ME. 2013. Drought, deluge and declines: the impact of precipitation extremes on amphibians in a changing climate. Biology 2: 399-418.

Received: 21 January 2017

Revised and accepted: 10 November 2017

Published online: 22 December 2017

Editor: J.W. Arntzen 


\section{Supplementary Information}

Table S1. List of all samples for which DNA sequences were produced in this study. For each sample we indicate sample ID, species name, collection locality and GenBank accession number $\$$, New range extension.

\begin{tabular}{|c|c|c|c|c|c|c|c|c|}
\hline Sample ID & Species & \multicolumn{2}{|c|}{ Locality } & $16 S$ & COI & ND1 & ND2 & ND4 \\
\hline \multicolumn{9}{|c|}{ Amphibians } \\
\hline ACP1215 & $\begin{array}{l}\text { Aglyptodactylus } \\
\text { securifer }\end{array}$ & $\begin{array}{l}\text { Sahamalaza } \\
\text { Peninsula }\end{array}$ & Anketsakely & MG189395 & & & & \\
\hline ACP1226 & $\begin{array}{l}\text { Aglyptodactylus } \\
\text { securifer }\end{array}$ & $\begin{array}{l}\text { Sahamalaza } \\
\text { Peninsula }\end{array}$ & Anketsakely & MG189396 & & & & \\
\hline ACP1230 & $\begin{array}{l}\text { Aglyptodactylus } \\
\text { securifer }\end{array}$ & $\begin{array}{l}\text { Sahamalaza } \\
\text { Peninsula }\end{array}$ & Anketsakely & MG189397 & & & & \\
\hline ACP1244 & $\begin{array}{l}\text { Aglyptodactylus } \\
\text { securifer }\end{array}$ & $\begin{array}{l}\text { Sahamalaza } \\
\text { Peninsula }\end{array}$ & Betsimipoaka & MG189398 & & & & \\
\hline ACP1063 & $\begin{array}{l}\text { Blommersia sp. } \\
\text { Ca05 (UCS) }\end{array}$ & $\begin{array}{l}\text { Sahamalaza } \\
\text { Peninsula }\end{array}$ & Ankarafa \$ & MG189399 & & & & \\
\hline ACP1064 & $\begin{array}{l}\text { Blommersia sp. } \\
\text { Ca05 (UCS) }\end{array}$ & $\begin{array}{l}\text { Sahamalaza } \\
\text { Peninsula }\end{array}$ & Ankarafa \$ & MG189400 & & & & \\
\hline ACP1140 & $\begin{array}{l}\text { Blommersia sp. } \\
\mathrm{Ca} 05 \text { (UCS) }\end{array}$ & $\begin{array}{l}\text { Sahamalaza } \\
\text { Peninsula }\end{array}$ & Ankarafa \$ & MG189401 & & & & \\
\hline ACP1175 & $\begin{array}{l}\text { Blommersia sp. } \\
\text { Ca05 (UCS) }\end{array}$ & $\begin{array}{l}\text { Sahamalaza } \\
\text { Peninsula }\end{array}$ & Ankarafa \$ & MG189402 & & & & \\
\hline ACP1179 & $\begin{array}{l}\text { Blommersia sp. } \\
\text { Ca05 (UCS) }\end{array}$ & $\begin{array}{l}\text { Sahamalaza } \\
\text { Peninsula }\end{array}$ & Ankarafa \$ & MG189403 & & & & \\
\hline ACP1197 & $\begin{array}{l}\text { Blommersia sp. } \\
\mathrm{Ca} 05 \text { (UCS) }\end{array}$ & $\begin{array}{l}\text { Sahamalaza } \\
\text { Peninsula }\end{array}$ & Anketsakely \$ & MG189404 & & & & \\
\hline ACP1146 & $\begin{array}{l}\text { Blommersia sp. } \\
\text { Ca05 (UCS) }\end{array}$ & $\begin{array}{l}\text { Sahamalaza } \\
\text { Peninsula }\end{array}$ & Ankarafa \$ & MG189405 & & & & \\
\hline ACP1152 & $\begin{array}{l}\text { Blommersia sp. } \\
\text { Ca05 (UCS) }\end{array}$ & $\begin{array}{l}\text { Sahamalaza } \\
\text { Peninsula }\end{array}$ & Ankarafa \$ & MG189406 & & & & \\
\hline ACP1153 & $\begin{array}{l}\text { Blommersia sp. } \\
\text { Ca05 (UCS) }\end{array}$ & $\begin{array}{l}\text { Sahamalaza } \\
\text { Peninsula }\end{array}$ & Ankarafa \$ & MG189407 & & & & \\
\hline ACP1165 & $\begin{array}{l}\text { Blommersia sp. } \\
\text { Ca05 (UCS) }\end{array}$ & $\begin{array}{l}\text { Sahamalaza } \\
\text { Peninsula }\end{array}$ & Ankarafa \$ & MG189408 & & & & \\
\hline ACP1061 & $\begin{array}{l}\text { Boophis } \\
\text { ankarafensis }\end{array}$ & $\begin{array}{l}\text { Sahamalaza } \\
\text { Peninsula }\end{array}$ & Ankarafa & MG189409 & & & & \\
\hline ACP1062 & $\begin{array}{l}\text { Boophis } \\
\text { ankarafensis }\end{array}$ & $\begin{array}{l}\text { Sahamalaza } \\
\text { Peninsula }\end{array}$ & Ankarafa & MG189410 & & & & \\
\hline ACP1185 & $\begin{array}{l}\text { Boophis } \\
\text { ankarafensis }\end{array}$ & $\begin{array}{l}\text { Sahamalaza } \\
\text { Peninsula }\end{array}$ & Ankarafa & MG189411 & & & & \\
\hline ACP1186 & $\begin{array}{l}\text { Boophis } \\
\text { ankarafensis }\end{array}$ & $\begin{array}{l}\text { Sahamalaza } \\
\text { Peninsula }\end{array}$ & Ankarafa & MG189412 & & & & \\
\hline ACP1184 & Boophis jaegeri & $\begin{array}{l}\text { Sahamalaza } \\
\text { Peninsula }\end{array}$ & Ankarafa & MG189413 & & & & \\
\hline ACP1193 & Boophis jaegeri & $\begin{array}{l}\text { Sahamalaza } \\
\text { Peninsula }\end{array}$ & Anketsakely & MG189414 & & & & \\
\hline ACP1194 & Boophis jaegeri & $\begin{array}{l}\text { Sahamalaza } \\
\text { Peninsula }\end{array}$ & Anketsakely & MG189415 & & & & \\
\hline
\end{tabular}




\begin{tabular}{|c|c|c|c|c|c|c|c|c|}
\hline Sample ID & Species & & & $16 S$ & COI & ND1 & ND2 & ND4 \\
\hline ACP1196 & Boophis jaegeri & $\begin{array}{l}\text { Sahamalaza } \\
\text { Peninsula }\end{array}$ & Anketsakely & MG189416 & & & & \\
\hline ACP1218 & Boophis jaegeri & $\begin{array}{l}\text { Sahamalaza } \\
\text { Peninsula }\end{array}$ & Anketsakely & MG189417 & & & & \\
\hline ACP1148 & Boophis brachychir & $\begin{array}{l}\text { Sahamalaza } \\
\text { Peninsula }\end{array}$ & Ankarafa \$ & MG189418 & & & & \\
\hline ACP1149 & Boophis brachychir & $\begin{array}{l}\text { Sahamalaza } \\
\text { Peninsula }\end{array}$ & Ankarafa \$ & MG189419 & & & & \\
\hline ACP1150 & Boophis brachychir & $\begin{array}{l}\text { Sahamalaza } \\
\text { Peninsula }\end{array}$ & Ankarafa \$ & MG189420 & & & & \\
\hline ACP1177 & Boophis brachychir & $\begin{array}{l}\text { Sahamalaza } \\
\text { Peninsula }\end{array}$ & Ankarafa \$ & MG189421 & & & & \\
\hline ACP1192 & Boophis brachychir & $\begin{array}{l}\text { Sahamalaza } \\
\text { Peninsula }\end{array}$ & Anketsakely \$ & MG189422 & & & & \\
\hline ACP1195 & Boophis brachychir & $\begin{array}{l}\text { Sahamalaza } \\
\text { Peninsula }\end{array}$ & Anketsakely \$ & MG189423 & & & & \\
\hline ACP1221 & Boophis brachychir & $\begin{array}{l}\text { Sahamalaza } \\
\text { Peninsula }\end{array}$ & Anketsakely \$ & MG189424 & & & & \\
\hline ACP1163 & $\begin{array}{l}\text { Boophis } \\
\text { tephraeomystax }\end{array}$ & $\begin{array}{l}\text { Sahamalaza } \\
\text { Peninsula }\end{array}$ & Ankarafa & MG189425 & & & & \\
\hline ACP1158 & $\begin{array}{l}\text { Boophis } \\
\text { tephraeomystax }\end{array}$ & $\begin{array}{l}\text { Sahamalaza } \\
\text { Peninsula }\end{array}$ & Ankarafa & MG189426 & & & & \\
\hline ACP1167 & $\begin{array}{l}\text { Boophis } \\
\text { tephraeomystax }\end{array}$ & $\begin{array}{l}\text { Sahamalaza } \\
\text { Peninsula }\end{array}$ & Ankarafa & MG189427 & & & & \\
\hline ACP1245 & $\begin{array}{l}\text { Boophis } \\
\text { tephraeomystax }\end{array}$ & $\begin{array}{l}\text { Sahamalaza } \\
\text { Peninsula }\end{array}$ & Betsimipoaka & MG189428 & & & & \\
\hline ACP1235 & $\begin{array}{l}\text { Boophis } \\
\text { tephraeomystax }\end{array}$ & $\begin{array}{l}\text { Sahamalaza } \\
\text { Peninsula }\end{array}$ & Anketsakely & MG189429 & & & & \\
\hline ACP1219 & Boophis tsilomaro & $\begin{array}{l}\text { Sahamalaza } \\
\text { Peninsula }\end{array}$ & Anketsakely \$ & MG189430 & & & & \\
\hline ACP1224 & Boophis tsilomaro & $\begin{array}{l}\text { Sahamalaza } \\
\text { Peninsula }\end{array}$ & Anketsakely \$ & MG189431 & & & & \\
\hline ACP1227 & Boophis tsilomaro & $\begin{array}{l}\text { Sahamalaza } \\
\text { Peninsula }\end{array}$ & Anketsakely \$ & MG189432 & & & & \\
\hline ACP1237 & Boophis tsilomaro & $\begin{array}{l}\text { Sahamalaza } \\
\text { Peninsula }\end{array}$ & Anketsakely \$ & MG189433 & & & & \\
\hline ACP1138 & Cophyla berara & $\begin{array}{l}\text { Sahamalaza } \\
\text { Peninsula }\end{array}$ & Ankarafa \$ & MG189434 & & & & \\
\hline ACP1657 & Cophyla berara & $\begin{array}{l}\text { Sahamalaza } \\
\text { Peninsula }\end{array}$ & Sahamalaza \$ & MG189435 & & & & \\
\hline ACP1157 & Cophyla berara & $\begin{array}{l}\text { Sahamalaza } \\
\text { Peninsula }\end{array}$ & Ankarafa \$ & MG189436 & & & & \\
\hline ACP1168 & Cophyla berara & $\begin{array}{l}\text { Sahamalaza } \\
\text { Peninsula }\end{array}$ & Ankarafa \$ & MG189437 & & & & \\
\hline ACP1204 & Cophyla berara & $\begin{array}{l}\text { Sahamalaza } \\
\text { Peninsula }\end{array}$ & Berara & MG189438 & & & & \\
\hline ACP1205 & Cophyla berara & $\begin{array}{l}\text { Sahamalaza } \\
\text { Peninsula }\end{array}$ & Berara & MG189439 & & & & \\
\hline ACP1212 & Cophyla berara & $\begin{array}{l}\text { Sahamalaza } \\
\text { Peninsula }\end{array}$ & Berara & MG189440 & & & & \\
\hline ACP1214 & Cophyla berara & $\begin{array}{l}\text { Sahamalaza } \\
\text { Peninsula }\end{array}$ & Berara & MG189441 & & & & \\
\hline
\end{tabular}




\begin{tabular}{|c|c|c|c|c|c|c|c|c|}
\hline Sample ID & Species & & & $16 S$ & COI & ND1 & ND2 & ND4 \\
\hline ACP1172 & Cophyla berara & $\begin{array}{l}\text { Sahamalaza } \\
\text { Peninsula }\end{array}$ & Ankarafa \$ & MG189442 & & & & \\
\hline ACP1173 & Cophyla berara & $\begin{array}{l}\text { Sahamalaza } \\
\text { Peninsula }\end{array}$ & Ankarafa \$ & MG189443 & & & & \\
\hline ACP1174 & Cophyla berara & $\begin{array}{l}\text { Sahamalaza } \\
\text { Peninsula }\end{array}$ & Ankarafa \$ & MG189444 & & & & \\
\hline ACP1217 & $\begin{array}{l}\text { Gephyromantis } \\
\text { pseudoasper }\end{array}$ & $\begin{array}{l}\text { Sahamalaza } \\
\text { Peninsula }\end{array}$ & Berara & MG189445 & & & & \\
\hline ACP1187 & $\begin{array}{l}\text { Heterixalus } \\
\text { luteostriatus }\end{array}$ & $\begin{array}{l}\text { Sahamalaza } \\
\text { Peninsula }\end{array}$ & Ankarafa & MG189446 & & & & \\
\hline ACP1220 & $\begin{array}{l}\text { Heterixalus } \\
\text { luteostriatus }\end{array}$ & $\begin{array}{l}\text { Sahamalaza } \\
\text { Peninsula }\end{array}$ & Anketsakely & MG189447 & & & & \\
\hline ACP1228 & $\begin{array}{l}\text { Heterixalus } \\
\text { luteostriatus }\end{array}$ & $\begin{array}{l}\text { Sahamalaza } \\
\text { Peninsula }\end{array}$ & Anketsakely & MG189448 & & & & \\
\hline ACP1242 & $\begin{array}{l}\text { Heterixalus } \\
\text { luteostriatus }\end{array}$ & $\begin{array}{l}\text { Sahamalaza } \\
\text { Peninsula }\end{array}$ & Betsimipoaka & MG189449 & & & & \\
\hline ACP1232 & $\begin{array}{l}\text { Hoplobatrachus } \\
\text { tigerinus }\end{array}$ & $\begin{array}{l}\text { Sahamalaza } \\
\text { Peninsula }\end{array}$ & Anketsakely & MG189450 & & & & \\
\hline ACP1246 & Mantella ebenaui & $\begin{array}{l}\text { Sahamalaza } \\
\text { Peninsula }\end{array}$ & Anketsakely & MG189451 & & & & \\
\hline ACP1178 & Mantella ebenaui & $\begin{array}{l}\text { Sahamalaza } \\
\text { Peninsula }\end{array}$ & Ankarafa & MG189452 & & & & \\
\hline ACP1203 & Mantella ebenaui & $\begin{array}{l}\text { Sahamalaza } \\
\text { Peninsula }\end{array}$ & Berara & MG189453 & & & & \\
\hline ACP1139 & $\begin{array}{l}\text { Mantidactylus } \\
\text { ulcerosus }\end{array}$ & $\begin{array}{l}\text { Sahamalaza } \\
\text { Peninsula }\end{array}$ & Ankarafa & MG189454 & & & & \\
\hline ACP1141 & $\begin{array}{l}\text { Mantidactylus } \\
\text { ulcerosus }\end{array}$ & $\begin{array}{l}\text { Sahamalaza } \\
\text { Peninsula }\end{array}$ & Ankarafa & MG189455 & & & & \\
\hline ACP1144 & $\begin{array}{l}\text { Mantidactylus } \\
\text { ulcerosus }\end{array}$ & $\begin{array}{l}\text { Sahamalaza } \\
\text { Peninsula }\end{array}$ & Ankarafa & MG189456 & & & & \\
\hline ACP1145 & $\begin{array}{l}\text { Mantidactylus } \\
\text { ulcerosus }\end{array}$ & $\begin{array}{l}\text { Sahamalaza } \\
\text { Peninsula }\end{array}$ & Ankarafa & MG189457 & & & & \\
\hline ACP1154 & $\begin{array}{l}\text { Mantidactylus } \\
\text { ulcerosus }\end{array}$ & $\begin{array}{l}\text { Sahamalaza } \\
\text { Peninsula }\end{array}$ & Ankarafa & MG189458 & & & & \\
\hline ACP1155 & $\begin{array}{l}\text { Mantidactylus } \\
\text { ulcerosus }\end{array}$ & $\begin{array}{l}\text { Sahamalaza } \\
\text { Peninsula }\end{array}$ & Ankarafa & MG189459 & & & & \\
\hline ACP1164 & $\begin{array}{l}\text { Mantidactylus } \\
\text { ulcerosus }\end{array}$ & $\begin{array}{l}\text { Sahamalaza } \\
\text { Peninsula }\end{array}$ & Ankarafa & MG189460 & & & & \\
\hline ACP1166 & $\begin{array}{l}\text { Mantidactylus } \\
\text { ulcerosus }\end{array}$ & $\begin{array}{l}\text { Sahamalaza } \\
\text { Peninsula }\end{array}$ & Ankarafa & MG189461 & & & & \\
\hline ACP1171 & $\begin{array}{l}\text { Mantidactylus } \\
\text { ulcerosus }\end{array}$ & $\begin{array}{l}\text { Sahamalaza } \\
\text { Peninsula }\end{array}$ & Ankarafa & MG189462 & & & & \\
\hline ACP1176 & $\begin{array}{l}\text { Mantidactylus } \\
\text { ulcerosus }\end{array}$ & $\begin{array}{l}\text { Sahamalaza } \\
\text { Peninsula }\end{array}$ & Ankarafa & MG189463 & & & & \\
\hline ACP1189 & $\begin{array}{l}\text { Mantidactylus } \\
\text { ulcerosus }\end{array}$ & $\begin{array}{l}\text { Sahamalaza } \\
\text { Peninsula }\end{array}$ & Ankarafa & MG189464 & & & & \\
\hline ACP1191 & $\begin{array}{l}\text { Mantidactylus } \\
\text { ulcerosus }\end{array}$ & $\begin{array}{l}\text { Sahamalaza } \\
\text { Peninsula }\end{array}$ & Anketsakely & MG189465 & & & & \\
\hline ACP1200 & $\begin{array}{l}\text { Mantidactylus } \\
\text { ulcerosus }\end{array}$ & $\begin{array}{l}\text { Sahamalaza } \\
\text { Peninsula }\end{array}$ & Anketsakely & MG189466 & & & & \\
\hline ACP1201 & $\begin{array}{l}\text { Mantidactylus } \\
\text { ulcerosus }\end{array}$ & $\begin{array}{l}\text { Sahamalaza } \\
\text { Peninsula }\end{array}$ & Anketsakely & MG189467 & & & & \\
\hline
\end{tabular}




\begin{tabular}{|c|c|c|c|c|c|c|c|c|}
\hline \multirow{2}{*}{$\begin{array}{l}\text { Sample ID } \\
\text { ACP1247 }\end{array}$} & \multirow{2}{*}{$\begin{array}{l}\text { Species } \\
\text { Ptychadena } \\
\text { mascareniensis }\end{array}$} & \multicolumn{2}{|c|}{ Locality } & \multirow{2}{*}{$\begin{array}{l}\text { 16S } \\
\text { MG189468 }\end{array}$} & \multirow{2}{*}{$\begin{array}{l}\text { COI } \\
\text { MG189476 }\end{array}$} & \multirow[t]{2}{*}{ ND1 } & \multirow[t]{2}{*}{ ND2 } & \multirow[t]{2}{*}{ ND4 } \\
\hline & & $\begin{array}{l}\text { Sahamalaza } \\
\text { Peninsula }\end{array}$ & Betsimipoaka & & & & & \\
\hline ACP1160 & $\begin{array}{l}\text { Stumpffia } \text { sp. } \\
\text { aff. pygmaea } \mathrm{Ca} \\
\text { "Sahamalaza" (UCS) }\end{array}$ & $\begin{array}{l}\text { Sahamalaza } \\
\text { Peninsula }\end{array}$ & Ankarafa & MG189469 & & & & \\
\hline ACP1161 & $\begin{array}{l}\text { Stumpffia sp. } \\
\text { aff. pygmaea } \mathrm{Ca} \\
\text { "Sahamalaza" (UCS) }\end{array}$ & $\begin{array}{l}\text { Sahamalaza } \\
\text { Peninsula }\end{array}$ & Ankarafa & MG189470 & & & & \\
\hline ACP1162 & $\begin{array}{l}\text { Stumpffia sp. } \\
\text { aff. pygmaea Ca } \\
\text { "Sahamalaza" (UCS) }\end{array}$ & $\begin{array}{l}\text { Sahamalaza } \\
\text { Peninsula }\end{array}$ & Ankarafa & MG189471 & & & & \\
\hline ACP1199 & $\begin{array}{l}\text { Stumpffia sp. } \\
\text { aff. pygmaea } \mathrm{Ca} \\
\text { "Sahamalaza" (UCS) }\end{array}$ & $\begin{array}{l}\text { Sahamalaza } \\
\text { Peninsula }\end{array}$ & Anketsakely & MG189472 & & & & \\
\hline \multicolumn{9}{|l|}{ Reptiles } \\
\hline ACP1188 & $\begin{array}{l}\text { Amphiglossus } \\
\text { reticulatus }\end{array}$ & $\begin{array}{l}\text { Sahamalaza } \\
\text { Peninsula }\end{array}$ & Ankarafa & & MG189477 & & & \\
\hline ACP1238 & $\begin{array}{l}\text { Amphiglossus } \\
\text { reticulatus }\end{array}$ & $\begin{array}{l}\text { Sahamalaza } \\
\text { Peninsula }\end{array}$ & Anketsakely & & MG189478 & & & \\
\hline ACP1169 & $\begin{array}{l}\text { Blaesodactylus } \\
\text { ambonihazo }\end{array}$ & $\begin{array}{l}\text { Sahamalaza } \\
\text { Peninsula }\end{array}$ & Ankarafa \$ & & MG189479 & & & \\
\hline ACP1159 & Brookesia minima & $\begin{array}{l}\text { Sahamalaza } \\
\text { Peninsula }\end{array}$ & Ankarafa \$ & & MG189480 & & MG189539 & \\
\hline ACP1181 & Brookesia minima & $\begin{array}{l}\text { Sahamalaza } \\
\text { Peninsula }\end{array}$ & Ankarafa \$ & & MG189481 & & MG189540 & \\
\hline ACP2751 & Brookesia minima & $\begin{array}{l}\text { Sahamalaza } \\
\text { Peninsula }\end{array}$ & Ankarafa \$ & & MG189482 & & & \\
\hline ACP1202 & Brookesia stumpffi & $\begin{array}{l}\text { Sahamalaza } \\
\text { Peninsula }\end{array}$ & Berara & & MG189483 & & & \\
\hline ACP1222 & Brookesia stumpffi & $\begin{array}{l}\text { Sahamalaza } \\
\text { Peninsula }\end{array}$ & Anketsakely & & MG189484 & & & \\
\hline ACP1207 & Brookesia stumpffi & $\begin{array}{l}\text { Sahamalaza } \\
\text { Peninsula }\end{array}$ & Anketsakely & & MG189485 & & & \\
\hline ACP1209 & Brookesia stumpffi & $\begin{array}{l}\text { Sahamalaza } \\
\text { Peninsula }\end{array}$ & Berara & & MG189486 & & & \\
\hline ACP1156 & $\begin{array}{l}\text { Ebenavia inunguis } \\
\text { (clade } \mathrm{Cb})\end{array}$ & $\begin{array}{l}\text { Sahamalaza } \\
\text { Peninsula }\end{array}$ & Ankarafa \$ & & MG189487 & & & \\
\hline ACP1183 & $\begin{array}{l}\text { Ebenavia inunguis } \\
\text { (clade } \mathrm{Cb} \text { ) }\end{array}$ & $\begin{array}{l}\text { Sahamalaza } \\
\text { Peninsula }\end{array}$ & Ankarafa \$ & & MG189488 & & & \\
\hline ACP1170 & Furcifer oustaleti & $\begin{array}{l}\text { Sahamalaza } \\
\text { Peninsula }\end{array}$ & Ankarafa & & MG189489 & & & \\
\hline ACP1190 & Furcifer oustaleti & $\begin{array}{l}\text { Sahamalaza } \\
\text { Peninsula }\end{array}$ & Anketsakely & & MG189490 & & & \\
\hline ACP1210 & Furcifer pardalis & $\begin{array}{l}\text { Sahamalaza } \\
\text { Peninsula }\end{array}$ & Berara & & MG189491 & & & \\
\hline ACP1236 & Furcifer pardalis & $\begin{array}{l}\text { Sahamalaza } \\
\text { Peninsula }\end{array}$ & Anketsakely & & MG189492 & & & \\
\hline ACP1198 & Furcifer pardalis & $\begin{array}{l}\text { Sahamalaza } \\
\text { Peninsula }\end{array}$ & Anketsakely & & MG189493 & & & \\
\hline ACP1216 & Geckolepis humbolti & $\begin{array}{l}\text { Sahamalaza } \\
\text { Peninsula }\end{array}$ & Anketsakely \$ & & MG189494 & & & MG189526 \\
\hline ACP1680 & Geckolepis humbolti & $\begin{array}{l}\text { Sahamalaza } \\
\text { Peninsula }\end{array}$ & Sahamalaza \$ & & MG189495 & & & MG189527 \\
\hline
\end{tabular}




\begin{tabular}{|c|c|c|c|c|c|c|c|}
\hline Sample ID & Species & & lity & $16 S$ & COI & ND2 & ND4 \\
\hline ACP2531 & $\begin{array}{l}\text { Geckolepis sp. aff. } \\
\text { maculata (OTU A; } \\
\text { CCS) }\end{array}$ & $\begin{array}{l}\text { Sahamalaza } \\
\text { Peninsula }\end{array}$ & Anketsakely & & MG189496 & & MG189528 \\
\hline ACP1143 & $\begin{array}{l}\text { Hemidactylus } \\
\text { mercatorius }\end{array}$ & $\begin{array}{l}\text { Sahamalaza } \\
\text { Peninsula }\end{array}$ & Ankarafa & & MG189497 & & \\
\hline ACP1142 & $\begin{array}{l}\text { Lygodactylus } \\
\text { tolampyae }\end{array}$ & $\begin{array}{l}\text { Sahamalaza } \\
\text { Peninsula }\end{array}$ & Ankarafa & & MG189498 & & MG189529 \\
\hline ACP1180 & $\begin{array}{l}\text { Lygodactylus } \\
\text { tolampyae }\end{array}$ & $\begin{array}{l}\text { Sahamalaza } \\
\text { Peninsula }\end{array}$ & Ankarafa & & MG189499 & & MG189530 \\
\hline ACP2749 & $\begin{array}{l}\text { Lygodactylus } \\
\text { tolampyae }\end{array}$ & $\begin{array}{l}\text { Sahamalaza } \\
\text { Peninsula }\end{array}$ & Ankarafa & MG189473 & MG189500 & & \\
\hline ACP2750 & $\begin{array}{l}\text { Lygodactylus } \\
\text { tolampyae }\end{array}$ & $\begin{array}{l}\text { Sahamalaza } \\
\text { Peninsula }\end{array}$ & Ankarafa & MG189474 & MG189501 & & \\
\hline ACP1208 & $\begin{array}{l}\text { Madagascarophis } \\
\text { colubrinus }\end{array}$ & $\begin{array}{l}\text { Sahamalaza } \\
\text { Peninsula }\end{array}$ & Anketsakely & & MG189502 & & \\
\hline ACP1213 & $\begin{array}{l}\text { Madagascarophis } \\
\text { colubrinus }\end{array}$ & $\begin{array}{l}\text { Sahamalaza } \\
\text { Peninsula }\end{array}$ & Berara & & MG189503 & & \\
\hline ACP1240 & $\begin{array}{l}\text { Madagascarophis } \\
\text { colubrinus }\end{array}$ & $\begin{array}{l}\text { Sahamalaza } \\
\text { Peninsula }\end{array}$ & Anketsakely & & MG189504 & & \\
\hline ACP1241 & $\begin{array}{l}\text { Madagascarophis } \\
\text { colubrinus }\end{array}$ & $\begin{array}{l}\text { Sahamalaza } \\
\text { Peninsula }\end{array}$ & Anketsakely & MG189475 & MG189505 & & \\
\hline ACP1234 & $\begin{array}{l}\text { Madascincus } \\
\text { stumpffi }\end{array}$ & $\begin{array}{l}\text { Sahamalaza } \\
\text { Peninsula }\end{array}$ & Anketsakely \$ & & MG189506 & MG189536 & \\
\hline ACP1681 & $\begin{array}{l}\text { Madascincus } \\
\text { stumpffi }\end{array}$ & $\begin{array}{l}\text { Sahamalaza } \\
\text { Peninsula }\end{array}$ & Sahamalaza \$ & & MG189507 & MG189537 & \\
\hline ACP1147 & Oplurus cuvieri & $\begin{array}{l}\text { Sahamalaza } \\
\text { Peninsula }\end{array}$ & Ankarafa & & MG189508 & & MG189531 \\
\hline ACP1239 & Paroedura stumpffi & $\begin{array}{l}\text { Sahamalaza } \\
\text { Peninsula }\end{array}$ & Anketsakely & & MG189509 & & \\
\hline ACP1682 & Paroedura stumpffi & $\begin{array}{l}\text { Sahamalaza } \\
\text { Peninsula }\end{array}$ & Sahamalaza & & MG189510 & & \\
\hline ACP1243 & Pelomedusa subrufa & $\begin{array}{l}\text { Sahamalaza } \\
\text { Peninsula }\end{array}$ & Betsimipoaka \$ & & MG189511 & & \\
\hline ACP1182 & Phelsuma kochi & $\begin{array}{l}\text { Sahamalaza } \\
\text { Peninsula }\end{array}$ & Ankarafa \$ & & MG189512 & & \\
\hline ACP1233 & $\begin{array}{l}\text { Lycodryas } \\
\text { granuliceps }\end{array}$ & $\begin{array}{l}\text { Sahamalaza } \\
\text { Peninsula }\end{array}$ & Anketsakely & & MG189513 & & \\
\hline ACP1223 & $\begin{array}{l}\text { Trachylepis } \\
\text { gravenhorstii } \\
\text { (lineage 1, DCL) }\end{array}$ & $\begin{array}{l}\text { Sahamalaza } \\
\text { Peninsula }\end{array}$ & Anketsakely & & MG189514 & & \\
\hline ACP1151 & Uroplatus ebenaui & $\begin{array}{l}\text { Sahamalaza } \\
\text { Peninsula }\end{array}$ & Ankarafa & & & & MG189532 \\
\hline ACP1211 & Uroplatus ebenaui & $\begin{array}{l}\text { Sahamalaza } \\
\text { Peninsula }\end{array}$ & Berara & & & & MG189533 \\
\hline ACP1206 & Uroplatus henkeli & $\begin{array}{l}\text { Sahamalaza } \\
\text { Peninsula }\end{array}$ & Anketsakely & & MG189515 & & MG189525 \\
\hline ACP1225 & Uroplatus henkeli & $\begin{array}{l}\text { Sahamalaza } \\
\text { Peninsula }\end{array}$ & Anketsakely & & MG189516 & & MG189534 \\
\hline ACP1231 & Uroplatus henkeli & $\begin{array}{l}\text { Sahamalaza } \\
\text { Peninsula }\end{array}$ & Anketsakely & & MG189517 & & MG189535 \\
\hline ACP1229 & $\begin{array}{l}\text { Zonossaurus } \\
\text { laticaudatus }\end{array}$ & $\begin{array}{l}\text { Sahamalaza } \\
\text { Peninsula }\end{array}$ & Anketsakely & & MG189518 & MG189538 & \\
\hline
\end{tabular}

